Article

\title{
Thermo-Economic Analysis of Hybrid Solar-Geothermal Polygeneration Plants in Different Configurations
}

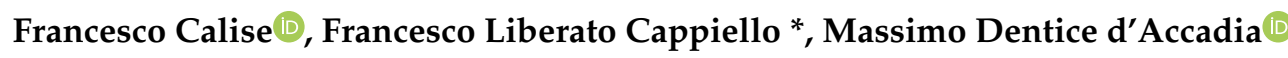 \\ and Maria Vicidomini \\ Department of Industrial Engineering, University of Naples Federico II, 80125 Naples, Italy; \\ frcalise@unina.it (F.C.); dentice@unina.it (M.D.d.); maria.vicidomini@unina.it (M.V.) \\ * Correspondence: francescoliberato.cappiello@unina.it
}

Received: 8 April 2020; Accepted: 5 May 2020; Published: 11 May 2020

\begin{abstract}
This work presents a thermoeconomic comparison between two different solar energy technologies, namely the evacuated flat-plate solar collectors and the photovoltaic panels, integrated as auxiliary systems into two renewable polygeneration plants. Both plants produce electricity, heat and cool, and are based on a 6 kWe organic Rankine cycle (ORC), a 17-kW single-stage H2O/LiBr absorption chiller, a geothermal well at $96^{\circ} \mathrm{C}$, a $200 \mathrm{kWt}$ biomass auxiliary heater, a $45.55 \mathrm{kWh}$ lithium-ion battery and a $25 \mathrm{~m}^{2}$ solar field. In both configurations, electric and thermal storage systems are included to mitigate the fluctuations due to the variability of solar radiation. ORC is mainly supplied by the thermal energy produced by the geothermal well. Additional heat is also provided by solar thermal collectors and by a biomass boiler. In an alternative layout, solar thermal collectors are replaced by photovoltaic panels, producing additional electricity with respect to the one produced by the ORC. To reduce ORC condensation temperature and increase the electric efficiency, a ground-cooled condenser is also adopted. All the components included in both plants were accurately simulated in a TRNSYS environment using dynamic models validated versus literature and experimental data. The ORC is modeled by zero-dimensional energy and mass balances written in Engineering Equation Solver and implemented in TRNSYS. The models of both renewable polygeneration plants are applied to a suitable case study, a commercial area near Campi Flegrei (Naples, South Italy), a location well-known for its geothermal sources and good solar availability. The economic results suggest that for this kind of plant, photovoltaic panels show lower pay back periods than evacuated flat-plate solar collectors, 13 years vs 15 years. The adoption of the electric energy storage system leads to an increase of energy-self-sufficiency equal to $42 \%$ and $47 \%$ for evacuated flat-plate solar collectors and the photovoltaic panels, respectively.
\end{abstract}

Keywords: hybrid renewable polygeneration plant; micro organic Rankine cycle; evacuated solar thermal collectors; photovoltaic panels

\section{Introduction}

Polygeneration plants based on renewable energy sources (RES) (geothermal, solar, biomass, wind and hydro), represent a suitable solution to reach the long-term goals expected by 2050, i.e., a reduction of greenhouse gas emissions by $80 \%-95 \%$ with respect to 1990 levels and a 100\% renewable electrical system. These targets are potentially achievable by considering that policies will continue to support renewable electricity worldwide, increasingly through competitive actions rather than feed-in tariffs, and by the transformation of the power sector amplified by rapid deployment of solar photovoltaic (PV) panels and wind turbine. An RES polygeneration plant can replace the existing 
conventional technologies based on fossil fuels and simultaneously produce several energy vectors (thermal, cooling and electric energy) and other outputs, by reducing significantly the primary energy consumption and $\mathrm{CO}_{2}$ emissions [1].

Several studies presented in literature about renewable polygeneration plants investigate the integration of renewable systems with different conventional systems: electric heat pump, trigeneration, gas-fired boiler, district heating and cooling and combined heating, cooling and power CHCP plants [2] for different purposes and application. In the context of power plants, the organic Rankine cycles (ORCs) [3] represent an interesting opportunity when coupled with low-medium enthalpy energy sources (biomass products [4], geothermal [5], solar [6,7], waste heat [8], ocean thermal energy [9], etc.). ORC plants adopt specific organic fluids showing an energy performance considerably better than water used in the conventional Rankine cycles, due to a higher molecular weight, lower evaporation heat, positive slope of the saturated vapor curve in the T-s diagram and lower critical and boiling temperatures [6]. In addition, for small scale units, ORC turbines are today an interesting technology, demonstrating several advantages in terms of operation life, maintenance and part-load efficiency.

Although the rapid increase in PV application, it is well-known that solar electric production is extremely variable due to the fluctuations of the solar radiation. This leads to an important increase in the electricity bought from the grid during the night, when the PV production is null, and during low solar availability hours, with the consequent reduction of the plant profitability. Therefore, the hybridization of different power systems (PV panels, PV and thermal (PVT) panels, wind turbines, ORC power plants) and the adoption of suitable electricity storage systems (ESSs) [10] with the proper ESS size determination in renewable energy systems [11] to obtain a more stable availability of the electric energy production, is an attractive solution to be investigated.

The simulation of polygeneration plants based on ORC power plants supplied by low and medium-temperature energy sources is diffusely investigated in the literature. Particularly, the integration of solar and geothermal sources is one of the most attractive configurations, mainly in volcanic areas featured by high solar radiation availability [6]. Thermal energy sources at low and medium temperature, typically within $90-130^{\circ} \mathrm{C}$, obtainable by solar and/or geothermal ones, are often used as input for supplying absorption chillers (ACH), multi-effect distillation (MED) systems and ORC in a unique renewable polygeneration plant. In the following section, an overview of the renewable power plants based on ORC technology coupled with PV/PVT panels and/or low-temperature geothermal energy is provided. In addition, studies investigating the combination of several thermal activated technologies (ACH, MED, ORC, etc.) in different plant configurations are also reported.

A hybrid solar and geothermal polygeneration plant, producing thermal energy for solar space heating/cooling (SHC), domestic hot water (DHW), fresh water and electric energy was studied by Calise et al. [6]. The plant includes different technologies: geothermal wells at about $80^{\circ} \mathrm{C}$, concentrating photovoltaic and thermal (CPVT) collectors, producing heat at about $100{ }^{\circ} \mathrm{C}$, a single-stage $\mathrm{LiBr} / \mathrm{H}_{2} \mathrm{O}$ $\mathrm{ACH}$ and a MED unit. The low-enthalpy geothermal energy, combined with the solar thermal energy, supplies the MED unit for fresh water production. Geothermal energy is also used to produce DHW at $45^{\circ} \mathrm{C}$. A dynamic simulation model is developed to simulate the whole plant performance and is applied to a suitable case study, the Pantelleria island and further volcanic Mediterranean islands. The pay back periods achieved for all the examined weather zones were extremely low, equal to about two years. Cheng Zhou [12] investigated a solar-geothermal hybrid plant, consisting of parabolic trough collectors, an ORC machine and a geothermal well at about $150^{\circ} \mathrm{C}$. Isopentane working fluid is adopted as working fluid and the ORC machine performance is evaluated by considering the subcritical and supercritical cycle. The studied ORC uses an air-cooled condenser for the condensation process and the exhaust fluid from the turbine by means of a recuperator. To perform the plant simulations, the Aspen HYSYS simulation tool is adopted. The supercritical ORC plant exhibits the better performance, producing from $4 \%$ to $17 \%$ more power and presenting from $4 \%$ to $19 \%$ lower solar-to-electricity cost with respect to the subcritical ORC plant. 
The performance evaluation of several types of PV materials (silicon, gallium arsenide, indium phosphide, cadmium sulfide and triple-junction indium gallium phosphide/indium gallium arsenide (germanium) in a system producing electricity using PV panels and utilizing the waste heat from the cells to drive an ORC is investigated by Tourkov and Schaefer [13]. Here, the performance of a variety of fluids as working fluids for the ORC is analyzed. It was found that n-butane is the optimal selection for the proposed application and that triple-junction cells at high concentration combined with an ORC were able to achieve over $45 \%$ solar efficiency. Kosmadakis et al. [14] carried out an experimental investigation of a small-scale low-temperature ORC machine coupled with CPVT collectors. R404A is selected as working fluid. The CPVT collectors produce electricity and heat and supply it to the ORC. The tests showed that such low-temperature ORC unit exhibits a fair efficiency and that its coupling with a solar field was feasible, increasing the power production of the whole system. The most important result from the laboratory tests is that the ORC machine with a capacity of $3 \mathrm{~kW}$ reached an adequate thermal efficiency, about $5 \%$, when operated at a very low temperature. An energy and exergy analysis of a hybrid polygeneration plant based on solar collectors and medium-high enthalpy geothermal sources is presented by Bicer and Dincer [15]. The plant is designed for simultaneously producing electricity, drying air, hot water and space heating and cooling. The heat provided by the geothermal energy and an air PVT drives an ORC for producing power. The ORC waste heat is employed for the activation of a $\mathrm{LiBr} / \mathrm{H}_{2} \mathrm{O} \mathrm{ACH}$, which provides the energy for space cooling of a dairy farm. Whereas the energy for space heating is provided by an electric heat pump. Moreover, the outlet hot air provided by the PVT collectors was employed for the food drying process of the farm. The polygeneration plant here proposed achieved global exergy and energy efficiencies of $28 \%$ and $11 \%$, respectively. The energy and exergy efficiencies of the ORC were $9 \%$ and $42 \%$, respectively. The air PVT collectors reached an exergy efficiency of $12 \%$. The COP and exergy of the $\mathrm{ACH}$ and electric heat pumps were 0.73 and 0.21 , and 4.1 and 0.03 , respectively. The optimal design of a hybrid solar power generation system for isolated zones, consisting of PV panels, diesel generators, batteries and an ORC machine is addressed in the work of Noguera et al. [16]. The novelty of this study is the adoption of the heat recovery of the exhaust gases from the diesel generator to supply the ORC machine. The selected objective function is the cost of power generation by considering as variables the nominal power of the diesel generator and the number of PV panels and batteries. Simulation results for the selected case study, the Cujubim city in Rondônia State, suggest that the optimized diesel-ORC-PV-battery hybrid system, including $6288 \mathrm{~kW}$ diesel generators, is able to obtain a generation cost of $\$ 0.301 / \mathrm{kWh}$, reduced approximately of $38.15 \%$ in comparison with the generation cost of a diesel system.

The above-presented literature review shows that numerous studies have examined the use of the waste heat from PVT panels for various applications, whereas there is limited research about the optimization of a combined PV panels/ORC machine system [13]. This combination could present a potential benefit in terms of efficiency and electricity cost if compared with the one of concentrating PV panels. Also, the reported literature review shows hybrid renewable energy polygeneration plants supplied by geothermal and solar energy, based on thermally-activated technologies and ORC, are investigated in different and several plant configurations. These works often examined medium-high scale ORC, with the exception of the ORC machines presented in references [5,14]. Specifically, the work presented in reference [5] is developed by some of the authors of this paper. Here a $6 \mathrm{~kW}$ micro-scale ORC machine supplied by solar and geothermal energy is investigated. In particular, a $25 \mathrm{~m}^{2}$ solar field consisting of flat-plate evacuated thermal collectors (ETCs) is coupled with a geothermal well at $96{ }^{\circ} \mathrm{C}$ to produce DHW, thermal energy, cooling energy by a single-stage $\mathrm{LiBr} / \mathrm{H}_{2} \mathrm{O} \mathrm{ACH}$ and electricity by an ORC, for a hotel located in Ischia (South Italy). With respect to the paper presented in reference [5], where all the outputs produced by the plant are assumed to be fully consumed by the user, in this study the power production and the heat produced for space heating and cooling must match the real time-dependent loads of the investigated user, a commercial building located in Campi Flegrei, a famous volcanic area of Naples (South Italy). In addition, this paper also includes a further significant improvement, with respect to work reported in reference [5], 
since it presents a thermoeconomic comparison between two different solar layouts: in the first one, solar energy produced by ETC collectors is converted into electricity by an ORC; the second layout refers to a more mature and simple configuration where ETCs are replaced by PV panels, operating independently from the ORC, supplying additional electricity to the system. In other words, this work aims to compare an innovative complex solar geothermal plant with a simpler configuration including PV collectors, considering both energy and economic aspects. Finally, this paper also includes additional novelties: (i) in order to increase the renewable energy source utilization, both renewable polygeneration plants include a biomass auxiliary heater; (ii) an electric energy storage system based on lithium-ion technology is used to mitigate power production fluctuations; (iii) a ground-cooled condenser in order to provide the required cooling energy to the ORC and to the $\mathrm{ACH}$.

Aim of the Study

In this paper, dynamic simulation models of two hybrid renewable polygeneration plants based on a micro-scale ORC machine coupled with a single-stage $\mathrm{LiBr} / \mathrm{H}_{2} \mathrm{O}$ ACH for producing power, heating and cooling are developed. The dynamic modeling involves the hybridization of geothermal, solar and biomass energy, thermal and electric energy storage systems. The thermoeconomic performance of two hybrid renewable polygeneration plants (the first based on ETCs and the second one on PV panels) are also compared. The dynamic energy models, developed by the means of the well-known TRNSYS software, include the modeling of complex operation control strategies and all the included technologies: ETCs, PV panels, micro-scale ORC, ACH, biomass auxiliary heater, lithium-ion energy storage, commercial building and all the other system components as storage tanks, heat exchangers, diverters, pumps, mixers, controllers and fan coils. From the achieved results interesting design and operating guidelines can be usefully provided for similar renewable polygeneration plants located in zones where both solar and geothermal energy are available.

\section{System Layouts}

The layouts of both the renewable polygeneration plants (Cases ETC and PV) are shown in Figure 1. They mainly consist of a low-temperature geothermal well (at $96{ }^{\circ} \mathrm{C}$, depth $94 \mathrm{~m}$ ), equipped with a submerged geothermal brine pump and a downhole heat exchanger, $25 \mathrm{~m}^{2}$ of solar field (ETCs or PV panels), $6 \mathrm{~kW}$ ORC machine, $200 \mathrm{~kW}$ auxiliary biomass-fired heater $(\mathrm{AH}), 17 \mathrm{~kW}_{\mathrm{f}} \mathrm{H}_{2} \mathrm{O} / \mathrm{LiBr}$ single-stage absorption chiller $(\mathrm{ACH})$, stratified vertical storage tanks, ground-coupled heat exchangers, $45.55 \mathrm{kWh}$ lithium-ion energy storage system (ESS), equipped with an inverter and a $308.5 \mathrm{~m}^{2}$ commercial building. Note that the size of the PV and ETC field are assumed equal, in fact, the aim of the proposed analysis consists of studying the performance of these two layouts occupying the same surface. This is due to the fact that the considered zone is not too vast and, therefore, occupying less space is a remarkable positive aspect. The adoption of the ground-coupled heat exchangers allows one to enhance system efficiency since both ACH and ORC efficiency significantly increases when the temperature of the cold sink decreases. During the summer season, ground temperature is significantly lower than the air temperature. Conversely, in winter, ground temperature may be higher than that of the air. In this case, using outdoor air as a cold sink would be more efficient than the use of ground. However, for this specific case, the additional cost of an air cooler would not be balanced by the income determined by the higher ORC electrical production. Therefore, it is assumed to use the ground-coupled heat exchanger all year long. Note that in the ETC case, ORC is driven by the combination of geothermal energy and solar energy supplied by ETCs. Finally, additional auxiliary heat is supplied by the biomass auxiliary heater, $\mathrm{AH}$, which is used in order to achieve the minimum ORC activation temperature. Conversely, in the PV Case, the ORC is only supplied by geothermal energy and by the biomass AH. The overall electrical production is due both to the ORC and to the PV panels. The geothermal source supplies energy for both building space heating and cooling. In particular, the geothermal heat is directly exploited for building space heating, whereas the cooling energy is provided by an absorption chiller driven by the geothermal heat. The power demand of the user is met by the power production 
of the ORC (Case ETC) or by the power production of the ORC and PV panels (PV Case), by the electric energy stored in the lithium-ion battery and by the electricity withdrawn from the grid.

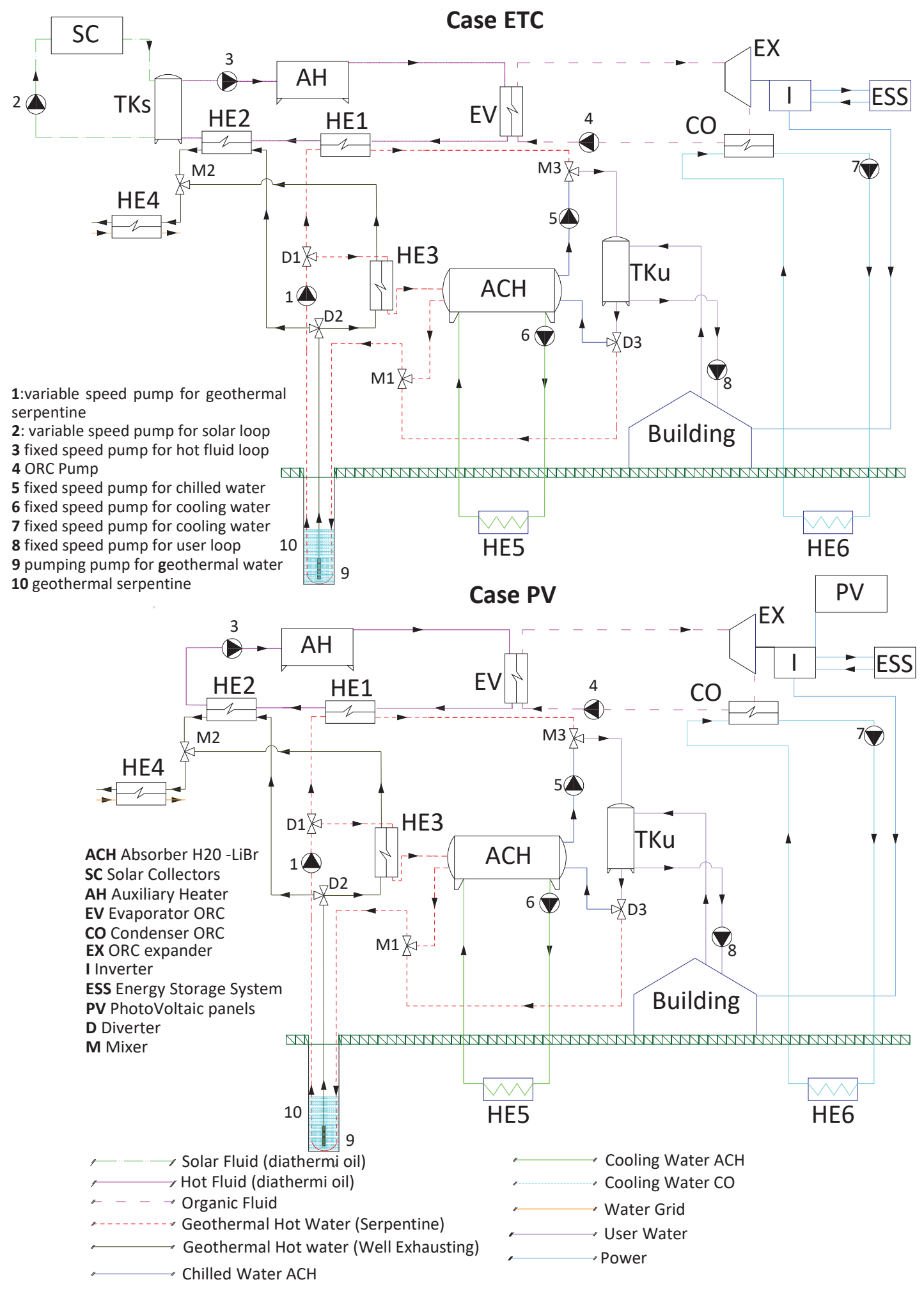

Figure 1. Systems layout: Case evacuated thermal collector (ETC, above) and Case photovoltaic (PV, below).

The layout of the examined plant consists of eleven main circuits: 
- The solar fluid (only in Case ETC), which describes the diathermic oil flowing between the stratified vertical storage solar tank (TKs) and the evacuated flat-plate solar collectors (SC) and TKs and the ORC evaporator (EV);

- The hot fluid referred to the diathermic oil flowing from the stratified vertical storage solar tank (TKs) and the evaporator (EV) of the ORC (Case ETC) and referred to the diathermic oil flowing from the heat exchangers HE2 and the evaporator (EV) of the ORC (Case PV);

- The organic fluid, describing the working fluid of ORC machine, which is R245fa;

- The geothermal hot water describes the hot water flowing into the downhole heat exchanger transferring thermal flow rate from the geothermal well to the heat exchangers HE3 in the summer and HE1 in the winter;

- The geothermal hot water well exhausting (the geothermal brine) employed to feed the heat exchangers HE3 in the summer and HE2 in the winter. The well exhausting is designed with the aim of getting a suction of the high temperature geothermal brine from the geothermal ground to the well, in order to maintain a continuously high temperature in the well;

- The chilled water, describes the cold water produced by the ACH and stored in TKu;

- The cooling water, represents the cooling loop of the absorber and condenser of $\mathrm{ACH}$, in particular, this loop exchange with the soil by means of the heat ground exchanger HE5;

- The cooling water of the condenser (CO), describes the cooling loop of the condenser of the ORC, which exchanges with the soil by the heat exchanger HE6;

- The water grid, the outlet geothermal hot water well exhausting (by the heat exchanger HE4) heats the grid water from 15 to $45^{\circ} \mathrm{C}$;

- The user water, described the heating/cooling water delivered to the fain coil unit inside the bar for building space heating/cooling purpose;

- The power circuit, which describes the power produced by the ORC expander (EX) (Case ETC) and by the PV panels and ORC expander (EX) (Case PV), the produced power is managed by the inverter (I) and sent to the system electric devices, building (Figure 2) and electric pumps, and subsequently employed for charging the energy storage system.

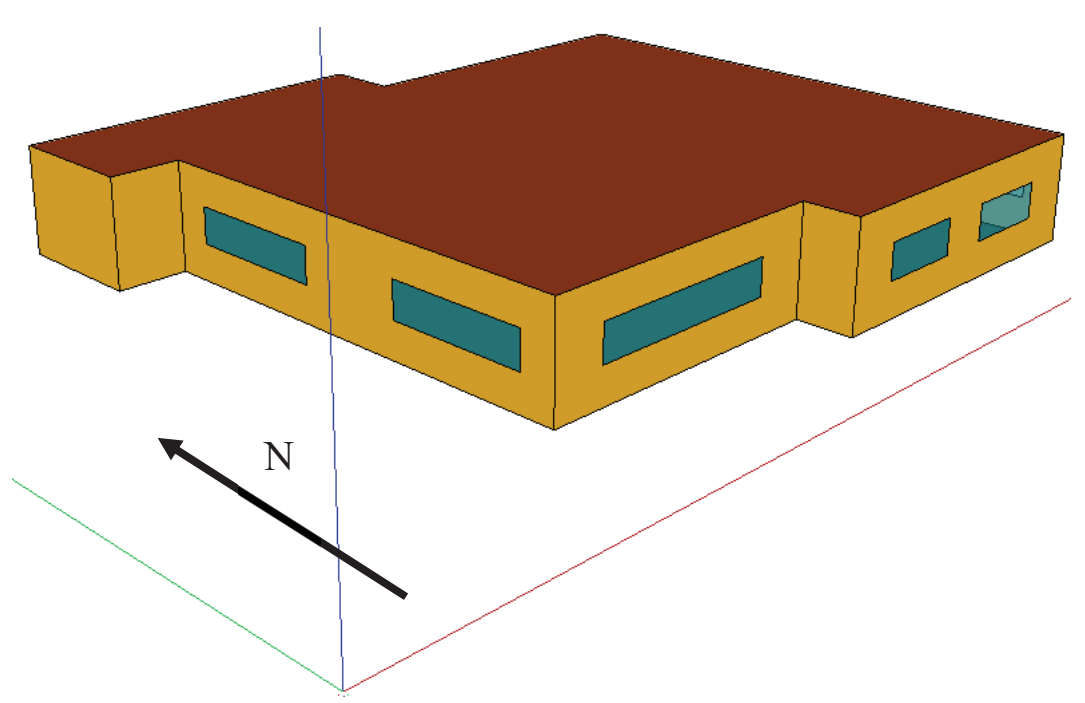

Figure 2. Building geometrical model.

Table 1 in detail reports the fluids adopted in each heat exchanger installed in the plant, the pumps and their seasonal scheduling.

According to the activation season of the several pumps and heat exchangers, during the winter season, D2 and D1 divert the geothermal brine and the geothermal hot water to HE2 and HE1, with the aim of heating the diathermic oil and obtain the minimum activation temperature of the ORC, i.e., 
$T_{\text {min, act, }, O R C}$, equal to $90^{\circ} \mathrm{C}$. The outlet temperature of the geothermal hot water from HE1 is exploited for providing thermal energy for the building space heating. The geothermal hot water is delivered to the tank of the user circuit (TKu) by M3. Then, the water is supplied by the P8 constant speed pump from $\mathrm{TKu}$ to the fan coil unit with the aim of reaching the selected set point indoor temperature, $T_{\text {set, heat }}$, equal to $20^{\circ} \mathrm{C}$.

Table 1. Heat exchangers and pumps.

\begin{tabular}{|c|c|c|c|}
\hline Heat Exchanger & Hot Side & Cold Side & Activation Season \\
\hline HE1 & Geothermal hot water & Diathermic oil * & \multirow{2}{*}{ Winter and summer ${ }^{*}$} \\
\hline HE2 & Geothermal brine & Diathermic oil & \\
\hline HE3 & Geothermal brine & Geothermal hot water & Summer \\
\hline HE4 & Geothermal brine & Grid water & All year \\
\hline HE5 & Cooling water $\mathrm{ACH}$ & \multirow{2}{*}{ Ground } & Summer \\
\hline HE6 & Cooling water $\mathrm{CO}$ of ORC & & All year \\
\hline Pumps & Variable or Constant Speed & Fluid & Activation Season \\
\hline P1 & variable & Geothermal hot water & \multirow{4}{*}{ All year } \\
\hline $\mathrm{P} 2$ & variable & Diathermic oil & \\
\hline P3 & \multirow{7}{*}{ Constant } & Diathermic oil & \\
\hline P4 & & R245fa & \\
\hline P5 & & Chilled water $\mathrm{ACH}$ & \multirow{2}{*}{ Summer } \\
\hline P6 & & Cooling water ACH & \\
\hline P7 & & Cooling water $\mathrm{CO}$ of ORC & \multirow{3}{*}{ All year } \\
\hline P8 & & Chilled or hot water & \\
\hline P9 & & Geothermal brine & \\
\hline
\end{tabular}

* The selected diathermic oil is a mixture consisted of biphenyl and diphenyl oxide. The analytical functions of the fluid properties are obtained by producer datasheets [17].

After the first preheating, performed by the geothermal thermal energy (HE1 and HE2), the diathermic oil is stored in the tank of the solar circuit. Then, the evacuated solar collector further heats the diathermic oil, to the selected set point temperature, $T_{s e t, S C}$, equal to $130{ }^{\circ} \mathrm{C}$. The operation of the solar fluid loop is managed by a feedback controller, which varies the flow rate of the variable speed pump P2. Therefore, the controller tries to reach the outlet set point temperature $T_{s e t, S C}$, reducing the P2 flow rate. In addition, the controller stops pump P2 if the TKs bottom temperature is higher the outlet temperature of the solar collector, for preventing the dissipation of the thermal energy stored in the TKs. The P3 constant speed pump supplies the diathermic oil at a variable temperature to the ORC evaporator. In particular, the ORC feeding temperature ranges from 90 to $130{ }^{\circ} \mathrm{C}$. When the top temperature of the tank TKs is lower than $T_{\min , a c t, O R C}$, a biomass condensing boiler is activated, increasing the temperature of the diathermic oil to $T_{\min , a c t, O R C}$.

During the summer season, the geothermal hot water is diverted to HE3 by D1, where the geothermal brine, diverted by the $\mathrm{D} 2$, further heats the geothermal hot water. This strategy allows the plant to reach a stable feeding temperature of the absorption chiller.

$\mathrm{ACH}$ is not in operation until the $T_{\text {bottom,TKu }}$ ranges between $6.5^{\circ} \mathrm{C}$ and $15^{\circ} \mathrm{C}$ (Table 2), then, in this case, also during the summer season, D2 and D1 respectively divert the geothermal brine and the geothermal hot water to HE2 and HE1, with the aim of increasing the thermal energy availability for the ORC machine. The constant speed pump P8 is activated for supplying the chilled water to the fan coil units, in order to achieve the selected set point indoor temperature, $T_{\text {set,cool }}$, equal to $26^{\circ} \mathrm{C}$. 
Table 2. Design and operating parameters (1).

\begin{tabular}{|c|c|c|c|c|}
\hline Component & Parameter & Description & Value & Unit \\
\hline \multirow{5}{*}{ GHE (HE5) } & $l_{G H E}$ & Ground heat exchanger length & $\mathrm{m}$ & 60 \\
\hline & $d_{G H E}$ & Ground heat exchanger diameter & $\mathrm{m}$ & 0.110 \\
\hline & $A_{G H E}$ & Ground heat exchanger area & $\mathrm{m}^{2}$ & 35 \\
\hline & $V_{\text {backfill }}$ & Backfill material volume & $\mathrm{m}^{3}$ & 7.2 \\
\hline & $h_{\text {conv }}$ & Flow convection coefficient & $\mathrm{W} /\left(\mathrm{K} \mathrm{m}^{2}\right)$ & 292 \\
\hline \multirow{5}{*}{ GHE (HE6) } & $l_{G H E}$ & Ground heat exchanger length & $\mathrm{m}$ & 18 \\
\hline & $d_{G H E}$ & Ground heat exchanger diameter & $\mathrm{m}$ & 0.050 \\
\hline & $A_{G H E}$ & Ground heat exchanger area & $\mathrm{m}^{2}$ & 4 \\
\hline & $V_{\text {backfill }}$ & Backfill material volume & $\mathrm{m}^{3}$ & 0.02 \\
\hline & $h_{\text {conv }}$ & Flow convection coefficient & $\mathrm{W} /\left(\mathrm{K} \mathrm{m}^{2}\right)$ & 58 \\
\hline \multirow{4}{*}{ HDPE } & $k_{H D E P}$ & Thermal conductivity & $\mathrm{W} /(\mathrm{m} \mathrm{K})$ & 0.49 \\
\hline & $\rho$ & Density of the material & $\mathrm{kg} / \mathrm{m}^{3}$ & 965 \\
\hline & $c_{p}$ & Specific heat of the material & $\mathrm{J} /(\mathrm{kg} \mathrm{K})$ & 2.25 \\
\hline & $\varepsilon$ & Roughness & $\mathrm{mm}$ & 0.3 \\
\hline \multirow{3}{*}{$\begin{array}{l}\text { Sand (backfill } \\
\text { material) }\end{array}$} & $k_{\text {backfill }}$ & Thermal conductivity & $\mathrm{W} /(\mathrm{m} \mathrm{K})$ & 1.5 \\
\hline & $\rho_{\text {backfill }}$ & Density of the material & $\mathrm{kg} / \mathrm{m}^{3}$ & 1500 \\
\hline & $c_{p, \text { backfill }}$ & Specific heat of the material & $\mathrm{J} /(\mathrm{kg} \mathrm{K})$ & 1798 \\
\hline \multirow{3}{*}{ Clay (ground) } & $k_{\text {soil }}$ & Thermal conductivity & $\mathrm{W} /(\mathrm{m} \mathrm{K})$ & 0.862 \\
\hline & $\rho_{\text {soil }}$ & Density of the material & $\mathrm{kg} / \mathrm{m}^{3}$ & 1430 \\
\hline & $c_{p, \text { backfill }}$ & Specific heat of the material & $\mathrm{J} /(\mathrm{kg} \mathrm{K})$ & 1439 \\
\hline \multirow{4}{*}{ I } & So $C_{L I B}$ & High and low limit on fractional state of charge & \multirow{4}{*}{ - } & $0.95-0.05$ \\
\hline & $\eta_{I, A C, t o, D C}$ & Efficiency (AC to DC) & & 0.98 \\
\hline & $\eta_{I, D C, t o, A C}$ & Efficiency (DC to AC) & & 0.96 \\
\hline & $\eta_{R}$ & Regulator efficiency & & 0.95 \\
\hline \multirow{6}{*}{ LIB } & $C_{\text {cell }}$ & Cell energy capacity & $\mathrm{Ah}$ & 63.27 \\
\hline & $V_{\text {battery }}$ & Battery voltage & $\mathrm{V}$ & 360 \\
\hline & $C_{\text {battery,aviable }}$ & Available capacity & $\mathrm{kWh}$ & 41.00 \\
\hline & $\eta_{L I B}$ & Battery efficiency & - & 0.9 \\
\hline & $P_{\text {LIB, discharge, } \max }$ & Maximum allowed discharging power & \multirow{2}{*}{$\mathrm{kW}$} & 10 \\
\hline & $P_{\text {LIB, discharge, } \max }$ & Maximum allowed charging power & & 10 \\
\hline \multirow{3}{*}{$\mathrm{ACH}$} & $P_{\text {rated }}$ & Rated cooling power & $\mathrm{kW}_{\mathrm{th}}$ & 17.1 \\
\hline & $\mathrm{COP}$ & Rated coefficient of performance & - & 0.7 \\
\hline & $T_{\text {set, }, A C H}$ & Set-point temperature for the chilled water & ${ }^{\circ} \mathrm{C}$ & 6.5 \\
\hline \multirow{2}{*}{$\mathrm{AH}$} & $P_{\text {rated }}$ & Rated auxiliary heater power & $\mathrm{kW}$ & 200 \\
\hline & $T_{s e t, A H}$ & Set point temperature for $\mathrm{AH}$ & 90 & ${ }^{\circ} \mathrm{C}$ \\
\hline \multirow{2}{*}{$\mathrm{TKu}$} & $H$ & Height & $\mathrm{m}$ & 0.5 \\
\hline & $V$ & Volume & $\mathrm{m}^{3}$ & 2 \\
\hline
\end{tabular}

Finally, M2 collects the geothermal brine exiting from HE3 and HE2, in order to exploit the waste heat of the geothermal brine for producing domestic hot water in HE4.

Note that due to the lack of a cold-water source the condenser of the ORC and $\mathrm{ACH}$ are cooled by ground-coupled heat exchangers HE6 and HE5.

The power produced by the ORC expander (Case ETC) and by the ORC expander and PV panels (Case PV) is delivered to the user through the regulator/inverter. When the power produced is greater than the power demand, including the power supplied to the auxiliary hydronic systems, the surplus 
power is employed for charging the lithium-ion battery. Note that the charge of the battery is allowed only if the battery state of charge $(\mathrm{SoC})$ ranges between the low and the high safe limit, assumed to be equal to $0.05\left(S o C_{\text {inf }}\right)$ and $0.95\left(S o C_{\text {sup }}\right)$, respectively (Table 2$)$. Note that if the lithium-ion battery is completely charged, and the building electric load is absent, the surplus power is delivered to the electric national grid. Finally, when the power produced and the stored energy in battery are not sufficient to match the power demand, the power is withdrawn from the electric national grid.

The adoption of a lithium-ion battery is affected by some criticism regarding the battery overheating as explained by many literature works [18-20]. The battery overheating is a dangerous aspect for the lithium-ion battery use, in fact, it may cause the battery to explode in the worst case but causes the degradation of the battery integrity and consequently the deterioration of its energy performances and the reduction of battery life-cycle [18-20]. This problem is caused by the high current intensity during the phase of charge and discharge of the battery, in fact, high current intensity leads to an increase of the temperature inside the battery. In conclusion, in order to prevent this problem, many literature works $([19,21,22])$ suggest limiting the discharge/charge power with respect to the maximum value (assumed equal to the power required to fully charge/discharge the battery in one hour). Therefore, the maximum allowed discharging/charging power is assumed to be equal to the power that would discharge/charge the battery in $4.5 \mathrm{~h}$, in order to achieve a battery life of 10 years [23].

\section{System Model}

The dynamic simulation models simulating the two renewable polygeneration plants shown in Section 2 are developed in the TRNSYS environment (version 17). This is a tool widely adopted both in academic and commercial areas. Some plant components (heat exchangers, $\mathrm{ACH}$, building, energy storage system, controllers, mixers, diverters, pumps, tanks, fan coil units, inverter, etc.) are simulated by the "types"(i.e., libraries) included into the TRNSYS library, whereas the models of the ORC machine and the geothermal well are developed by the authors of this work and presented in reference [5]. In this section, the models of the main components of both compared cases (Cases ETC and PV), i.e., the flat-plate ETCs and the PV panels and thermoeconomic model developed for evaluating the economic and energy performance of both plants are reported in detail. Note that the reliability of the results achieved by the developed models is based on the fact that all the components adopted are validated vs experimental data [24], vs data available in literature and/or based on manufacturers' data.

The data concerning the design and operating parameters of the main components of both the plants and the building simulation data are summarized in Tables $2-4$. Conversely, the data concerning the ORC machine and geothermal well are reported in reference [5].
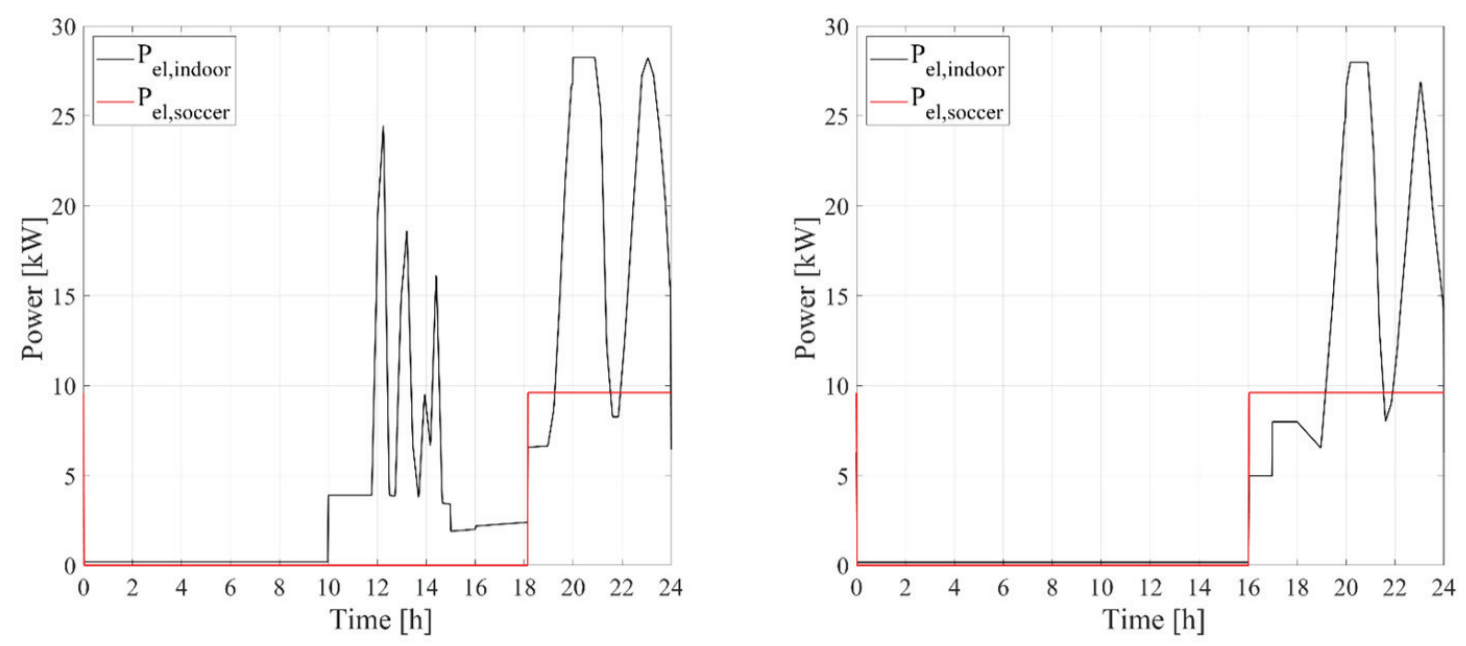

Figure 3. Daily electric load for a typical summer day (left) and for a typical winter day (right). 
Table 3. Design and operating parameters (2).

\begin{tabular}{|c|c|c|c|c|}
\hline Component & Parameter & Description & Value & Unit \\
\hline \multirow{14}{*}{ ETC } & $a_{1}$ & Zero collector heat loss coefficient & 0.399 & $\mathrm{Wm}^{-2} \mathrm{~K}^{-1}$ \\
\hline & $a_{2}$ & Temperature difference dependence of the heat loss coefficient & 0.0067 & $\mathrm{Wm}^{-2} \mathrm{~K}^{-2}$ \\
\hline & $a_{3}$ & Wind speed dependence of the heat loss coefficient & 0 & $\mathrm{Jm}^{-3} \mathrm{~K}^{-1}$ \\
\hline & $a_{4}$ & Long-wave radiation dependence of the collector & 0 & - \\
\hline & $a_{5}$ & Effective heat capacity of the collector & 7505 & $\mathrm{Jm}^{-2} \mathrm{~K}^{-1}$ \\
\hline & $a_{6}$ & Wind speed dependence in zero loss efficiency & 0 & $\mathrm{~ms}^{-1}$ \\
\hline & $A_{\text {ETC }}$ & Solar collector aperture area & 25 & $\mathrm{~m}^{2}$ \\
\hline & $q_{P 2}$ & $\mathrm{P} 2$ rated flow rate & 3960 & $\mathrm{~kg} / \mathrm{h}$ \\
\hline & $v_{T K}$ & Tank TK volume per unit SC aperture area & 5 & $1 / \mathrm{m}^{2}$ \\
\hline & $\eta_{0}$ & SC zero loss efficiency at normal incidence & 0.82 & - \\
\hline & $c_{f}$ & Diathermic oil specific heat & 1.8 & $\mathrm{~kJ} / \mathrm{kg} \mathrm{K}$ \\
\hline & $\alpha$ & Collector slope & 30 & 。 \\
\hline & $\beta$ & Collector azimuth & 0 & \\
\hline & $T_{\text {set,ETC }}$ & SC outlet set point temperature & 130 & ${ }^{\circ} \mathrm{C}$ \\
\hline \multirow{12}{*}{ PV } & $P_{\max }$ & Maximum power & 260 & $\mathrm{~W}_{\mathrm{p}}$ \\
\hline & $V_{o c}$ & Open-circuit voltage & 37.7 & $\mathrm{~V}$ \\
\hline & $I_{s c}$ & Short-circuit current & 9.01 & A \\
\hline & $V_{m p p}$ & Voltage at point of MPP & 30.5 & $\mathrm{~V}$ \\
\hline & $I_{m p p}$ & Current at point of MPP & 8.51 & A \\
\hline & $N_{s}$ & Number of modules in series & 2 & \multirow[t]{2}{*}{-} \\
\hline & $N_{p}$ & Number of modules in parallel & 50 & \\
\hline & $A$ & PV module area & 1.6 & $\mathrm{~m}^{2}$ \\
\hline & $N_{\text {cell }}$ & Number of cells in series & 15 & \multirow[t]{2}{*}{-} \\
\hline & $\eta_{P V}$ & Module efficiency & 15.8 & \\
\hline & $P_{\text {rated }, P V}$ & PV panel rated power & 7.63 & $\mathrm{~kW}$ \\
\hline & $A_{\text {tot }}$ & PV field area & 48.27 & $\mathrm{~m}^{2}$ \\
\hline
\end{tabular}

Table 4. Building simulation data.

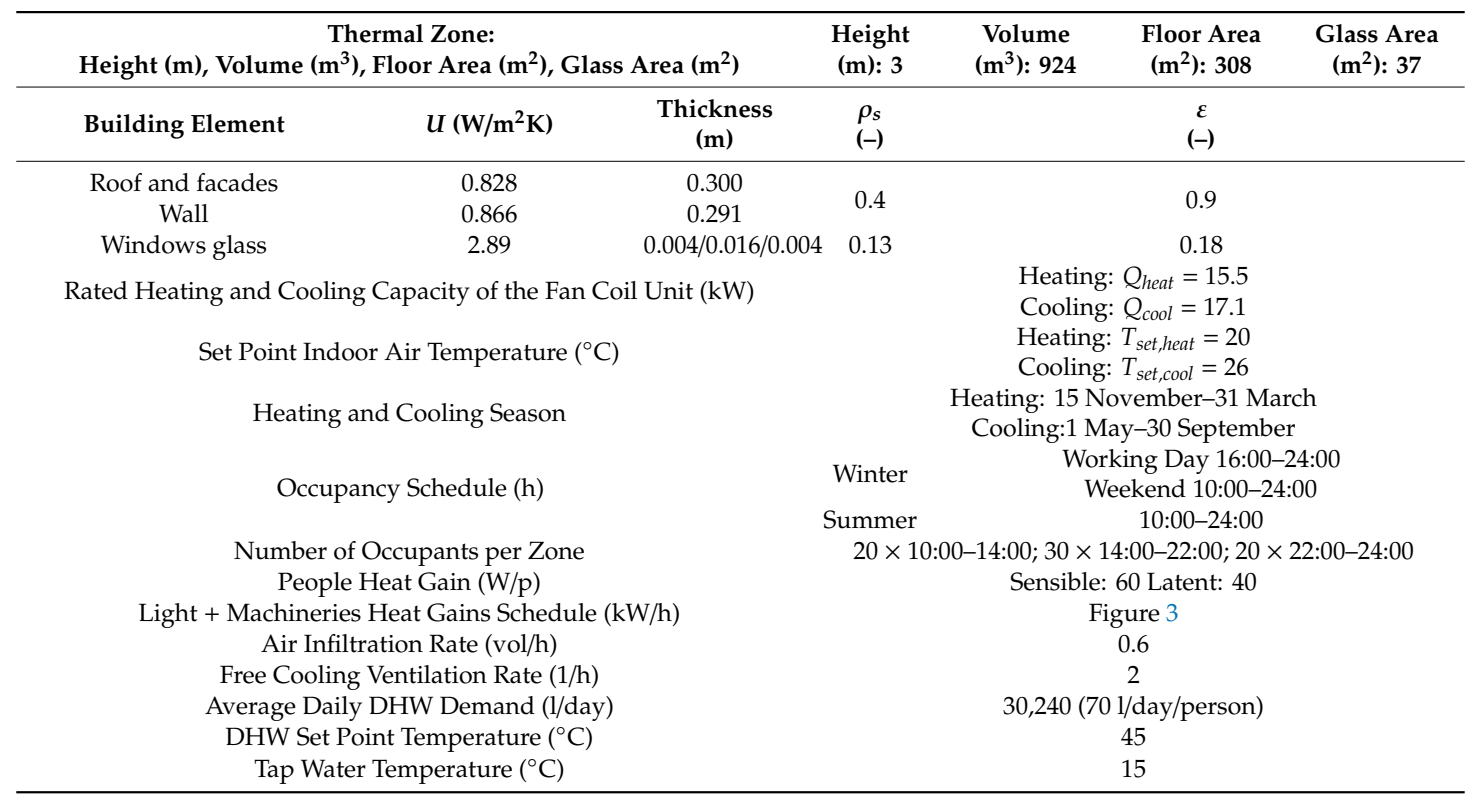




\subsection{Evacuated Thermal Collector Model}

The flat-plate evacuated solar collectors are modeled by considering the high-vacuum HT-Power collectors (version 4.0), designed and manufactured by the TVP Solar company [25]. In particular, the model, validated by several outdoors and indoors experimental campaigns, is based on a modified version of TRNSYS Type 132 [26], which considers the Hottel-Whillier equation integrated with the incidence angle modifier (IAM) coefficients (determined by the tests according to EN 12975 and EN 12976 [27]) and takes into account the wind effect on the zero loss efficiency, the wind influence on the heat losses and the long-wave irradiance dependence of the collector. Therefore, the heat transferred from the ETC per unit aperture at each time-step is:

$$
\begin{aligned}
& Q_{t h}=F^{\prime} \cdot(\tau \alpha)_{e n} \cdot\left\{\left[1-b_{0} \cdot\left(\frac{1}{\cos \theta_{b}}-1\right)\right] \cdot G_{b}+K_{\theta d} \cdot G_{d}\right\}-a_{1} \cdot\left(t_{m}-t_{a}\right) \\
& -a_{2} \cdot\left(t_{m}-t_{a}\right)^{2}-a_{3} \cdot u \cdot\left(t_{m}-t_{a}\right)-a_{4} \cdot\left(E_{L}-\sigma T_{a}^{4}\right)-a_{5} \cdot \frac{d t_{m}}{d t}-a_{6} \cdot u \cdot G
\end{aligned}
$$

where $F^{\prime} \cdot(\tau \alpha)_{e n}$ is the zero loss efficiency of the collector at normal incidence angle for the solar radiation onto the collector, $K_{\theta d}$ is the IAM for diffuse radiation, $G_{b}$ is the beam of solar radiation, $G_{d}$ is the diffuse radiation, the factor reported in square brackets is the incidence angle modifier (IAM) for beam radiation $\left(b_{0}\right.$ is the IAM determined by the collector test, $\theta_{b}$ is the incidence angle for beam radiation onto the solar collector plane). The description of the coefficients of Equation (1) and their numerical values are reported in Figure 3.

\subsection{PV Panel Model}

The PV panel model is based on the so-called "four parameters" model, which is implemented by the Type 94 using the manufacturers' data and generating the IV curve every time step. The four parameters used are: (i) $I_{L, \text { ref }}$, the photocurrent of module at reference condition; (ii) $I_{0, \text { ref, }}$, the diode reverse saturation current at reference condition; (iii) $\gamma$, the empirical PV curve-fitting parameter; (iv) $R_{S}$, the module series resistance. The main assumption of the model is that the slope of the IV curve at the short-circuit condition is zero. By considering $R_{s}$ and $\gamma$ to be constant, the current-voltage equation of the circuit is:

$$
I=I_{L, \text { ref }} \frac{G_{T}}{G_{T, \text { ref }}}-I_{o, \text { ref }}\left(\frac{T_{\mathcal{C}}}{T_{c, \text { ref }}}\right)^{3}\left[\exp \left(\frac{q}{\gamma k T_{\mathcal{C}}}\left(V+I R_{S}\right)\right)-1\right]
$$

where the current $I$ is a linear function of $G_{T}$, the total incident solar irradiance on the PV panel and $G_{T, r e f}$, the reference solar irradiance and depends on the temperature at the reference open-circuit condition $T_{c}$.

The current $\left(I_{m p p}\right)$ and the voltage $\left(V_{m p p}\right)$ at the maximum power point are evaluated by means of an iterative routine. Thus, the system of equations, that describes the four equivalent circuit characteristics, is solved. The first step is to substitute the voltage and current into Equation (2) at the short circuit, open-circuit and maximum power conditions. After some handling, one obtains the following three equations, that depend on $I_{L, \text { ref }}$ (Equation (3)), $\gamma$ (Equation (4)) and $I_{0, \text { ref }}$ (Equation (5)).

$$
\begin{gathered}
I_{L, r e f} \approx I_{s c, \text { ref }} \\
\gamma=\frac{q\left(V_{m p, r e f}-V_{o c, \text { ref }}+I_{m p, r e f} R_{s}\right)}{k T_{c, \text { ref }} \ln \left(1-\frac{I_{m p, r e f}}{I_{s c, \text { ref }}}\right)} \\
I_{o, \text { ref }}=I_{s c, \text { ref }} \exp ^{-\left(\frac{q V_{o c \text { ref }}}{\gamma k T_{c, \text { ref }}}\right)}
\end{gathered}
$$


Another equation is needed to determine the last unknown parameter, i.e., the temperature coefficient of open-circuit voltage. This parameter is obtained by the analytical derivate of voltage $V_{o c}$ with respect to $T_{c}$ :

$$
\frac{\partial V_{o c}}{\partial T_{c}}=\mu_{v o c}=\frac{\gamma k}{q}\left[\ln \left(\frac{I_{s c, \text { ref }}}{I_{o, \text { ref }}}\right)+\frac{T_{c} \mu_{\text {isc }}}{I_{s c, \text { ref }}}-\left(3+q \varepsilon\left(\frac{\gamma}{N_{s}} k T_{c, \text { ref }}\right)^{-1}\right)\right]
$$

where $\mu_{\text {isc }}$ is the temperature coefficient of short-circuit current, $N_{s}$ is the number of individual cells in a module, $q$ is the electron charge constant, $k$ is the Boltzmann constant, $\varepsilon$ is the semiconductor bandgap. The manufactures' specification about the open circuit temperature is equal to this analytical value. Therefore, a search routine is used iteratively to evaluate the equivalent open circuit characteristics.

\subsection{Thermoeconomic Model}

The energy and economic performance of both the renewable power plants are evaluated by the calculation of the primary energy saving (PES) and the simple pay back period (SPB) index. With this aim in mind, a suitable conventional reference system (RS) is selected to compare each plant with the same RS. The RS consists of a conventional vapor-compression chiller and a gas-fired heater for cooling and thermal energy production, respectively, whereas the national grid is the conventional system providing the electric energy to the user. The achievable PES by both renewable plants, in terms of electric, heating and cooling energy savings vs the conventional RS is calculated as in Equation (7).

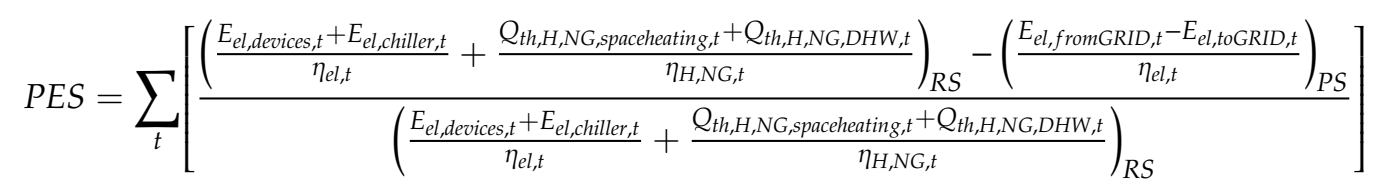

where $E_{\text {el,from } G R I D, t} / E_{e l, t o G R I D, t}$ are the electric energy withdrawn/sent from/to the national grid in the proposed system (PS), respectively, $Q_{t h, A H, b i o m a s s, t}$ is the thermal energy supplied by the auxiliary biomass-fired heater in PS, $\eta_{H, N G, t}$ and $\eta_{e l, t}$ are the natural gas-fired heater efficiency and conventional thermo-electric power plant efficiency, $E_{e l, c h i l l e r, t}$ and $E_{e l, \text { devices, } t}$ are the electric energy required by the compression chiller and by the electric devices of the building, respectively, in RS, $Q_{t h, H, N G, \text { spaceheating,t }}$ and $Q_{t h, H, N G, D H W, t}$ are the thermal energy supplied by the natural gas-fired heater for space heating and DHW, respectively, in RS.

The corresponding potential yearly economic savings $\Delta C$ achievable by both renewable plants are calculated by Equation (8). Here, the yearly operating costs of both PSs (Case ETC and Case PV) due to the yearly maintenance of an ORC machine $m_{O R C}$ and yearly maintenance of both solar fields $m_{S F}$ (ETCs and PV panels), are considered.

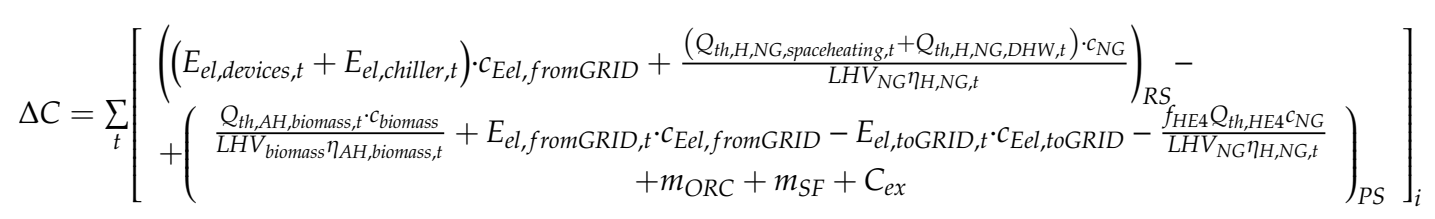

where $c_{\text {biomass }}$ is the biomass cost for the auxiliary biomass-fired heater, $C_{e x}$ is the fixed yearly cost due to the electric energy exchanged with the national grid, $c_{E e l, \text { fromGRID }}$ is the purchasing cost of the electric energy withdrawn from the national grid, $c_{E e l, t o G R I D}$ is the selling cost of the electric energy sent to the national grid. Note that if $f_{H E 4}=1$, the economic saving of the PS also takes into account the thermal energy recovered by heat exchanger HE4 for DHW production. Note that the same amount of DHW is produced in RS by a conventional gas-fired boiler.

The SPB is assessed as reported in Equation (9) 


$$
S P B=\frac{\sum_{i} J_{i}}{\Delta C}
$$

Here, the capital costs of all the components $J_{i}$ are considered. In particular, the capital costs for storage tanks, pumps and heat exchangers (HE1, HE2, HE3 HE4) are calculated by suitable polynomial equations [28] as a function of the rated volume, flow rate and heat exchange area, respectively. The unit capital costs assumed for the other components are summarized in Table 5. Concerning the heat exchangers HE5 and HE6, i.e., the ground-coupled heat exchangers, their capital cost $J_{G H E}$ is obtained by the calculation reported in Equation (10).

$$
J_{G H E}=c_{\text {excavation }} \cdot A_{G H E}+c_{\text {lenght }} \cdot l_{G H E}+c_{\text {backfill }} \cdot V_{\text {backfill }} \cdot \rho_{\text {backfill }}
$$

where $c_{\text {excavation }}$ is the excavation cost assumed equal to $80 € / \mathrm{m}^{2}, c_{\text {lenth }}$ is the specific cost of the horizontal pipe, assumed equal to $2.72 € / \mathrm{m}$ and $14.47 € / \mathrm{m}$ for HE6 and HE5, respectively, note that $c_{\text {length }}$ depends on the diameter dimension, $A_{G H E}$ is the area of the ground heat exchanger, $l_{G H E}$ is the length of the ground heat exchanger (the length of the buried horizontal pipes), $\rho_{\text {backfil }}$ and $V_{\text {backfil }}$ are the backfill material density and volume respectively, and $c_{\text {backfill }}$ is the cost of the backfill material (sand), assumed equal to $14.45 € / \mathrm{t}$ (Table 2).

\begin{tabular}{|c|c|c|c|}
\hline Parameter & Description & Value & Unit \\
\hline$J_{A C H}$ & $\mathrm{ACH}$ unit capital cost per $\mathrm{kW}$ of cooling capacity & 310 [2] & $€ / \mathrm{kW}$ \\
\hline$J_{\text {ETC }}$ & ETC unit capital cost per $\mathrm{m}^{2}$ of solar field & $300[29]$ & $€ / \mathrm{m}^{2}$ \\
\hline$J_{P V}$ & PV unit capital cost per $\mathrm{kW}_{\mathrm{el}}$ & $1000[30]$ & \multirow{3}{*}{$€ / \mathrm{kW}_{\mathrm{el}}$} \\
\hline JORC & ORC unit capital cost per $\mathrm{kW}_{\mathrm{el}}$ & $583[5]$ & \\
\hline$J_{I}$ & Inverter unit capital cost per $\mathrm{kW}_{\mathrm{el}}$ & $180[30]$ & \\
\hline$J_{E S S}$ & ESS unit capital cost per kWh of capacity & $346[31]$ & $€ / \mathrm{kWh}$ \\
\hline$c_{\text {Eel,from GRID }}$ & Electric energy purchasing unit cost & 0.17 & $€ / \mathrm{kWh}$ \\
\hline$c_{E e l, t o G R I D}$ & Electric energy selling unit cost & 0.08 & $€ / \mathrm{kWh}$ \\
\hline$c_{N G}$ & Natural gas unit cost & 0.88 & $€ / \mathrm{Sm}^{3}$ \\
\hline$c_{\text {biomass }}$ & Biomass gas unit cost & 0.06 & $€ / \mathrm{kg}$ \\
\hline$C_{e x}$ & Energy exchange yearly cost & 30 & $€ /$ year \\
\hline$m_{O R C}$ & ORC machine maintenance yearly cost & 1 & $\% /$ year \\
\hline$m_{S F, E T C}$ & Solar field maintenance yearly cost (Case ETC) & 2 & $\% /$ year \\
\hline$m_{S F, P V}$ & Solar field maintenance yearly cost (Case PV) & 2 & $\% /$ year \\
\hline LHV biomass & Biomass lower heating value & 3.7 & $\mathrm{kWh} / \mathrm{kg}$ \\
\hline$L H V_{N G}$ & Natural gas lower heating value & 9.6 & $\mathrm{kWh} / \mathrm{Sm}^{3}$ \\
\hline$\eta_{e l, t}$ & Conventional thermo-electric power plant efficiency & 46 & $\%$ \\
\hline$\eta_{H, N G, t}$ & Natural gas-fired heater efficiency. & 95 & $\%$ \\
\hline$\eta_{A H, b i o m a s s, t}$ & Auxiliary biomass-fired heater efficiency. & 95 & $\%$ \\
\hline
\end{tabular}

Table 5. Thermoeconomic assumptions.

Table 5 summarizes the thermoeconomic assumptions for the yearly economic saving.

\section{Case Study}

The analyzed case study refers to a real commercial user, located in Campi Flegrei (near Naples) worldwide famous for its volcanic activity. The geothermal well is located close to a small bar serving five small soccer fields. The proposed polygeneration system will provide electricity, thermal and 
cooling energy to this user which is also selected to perform the dynamic simulations and the related thermoeconomic analysis.

Two innovative micro renewable power plants are presented, based on the exploiting of the solar and the geothermal energy source. Note that concerning the geothermal source of energy an existing low-temperature geothermal well at the selected user is considered.

The first one (Case ETC) uses this geothermal well and a small solar field for feeding a $6 \mathrm{~kW}_{\mathrm{e}}$ ORC machine and produce electricity and to supply a $17.1 \mathrm{~kW}_{\mathrm{f}}$ absorption chiller (supplied by the geothermal energy only), the data about the solar field are reported in Table 3. The second one (Case PV) only differs from Case ETC, a photovoltaic field of $48.27 \mathrm{~m}^{2}$ is installed (design data displayed in Table 3) and no solar thermal plant is considered.

Note that ETC and PV areas are selected with the aim to obtain in both cases a similar cost. The scope of the analysis is to compare, at the same capital costs, PV and ETC configurations.

The geothermal well included in this case study was drilled several years ago for DHW production. However, due to its significantly high temperature compared to the other geothermal wells available in the selected zone, it is presently unused. Indeed, the selected zone is also rich in low temperature geothermal wells, which better suits the domestic hot water production. Whereas, the geothermal brine temperature is equal to about $96^{\circ} \mathrm{C}$. Therefore, this well is presently available for the research described in this work. The ORC machine is designed to be driven by the diathermic oil at an inlet temperature ranging between $90^{\circ} \mathrm{C}$ and $130{ }^{\circ} \mathrm{C}$, since the additional temperature increase can be provided by the solar field. Reference [5] in detail describes the ORC machine design parameters and operation. Note that the biomass condensing boiler is activated only if the temperature of the oil feeding ORC evaporator is below $90^{\circ} \mathrm{C}$ (Figure 1).

Note that the ground heat exchangers (HE5 and HE6) are selected to cool the condenser and absorber of $\mathrm{ACH}$ and the condenser of the ORC machine because in the selected location no suitable cold-water source is available. In addition, the installation of cooling towers and/or dry coolers is not feasible due to space availability and noise constraints.

The ground heat exchanger for the ACH (HE5) consists of a pump (P6, Figure 1 and Table 1) which feeds a $60 \mathrm{~m}$ long tube of high-density polyethylene (HDPE). The heat exchange occurs in this tube, which is buried at $5 \mathrm{~m}$ depth. The tube diameter is chosen equal to $0.110 \mathrm{~m}$ (Table 2). Moreover, a layer of sand surrounds the tube, as backfill material, with the aim of enhancing the heat exchange between clay ground and the pipe. The ground heat exchanger for the ORC (HE6) is developed with the same approach, Table 2 in detail describes the characteristics and the thermodynamic features of both the ground heat exchangers.

The commercial area consists of a $308.5 \mathrm{~m}^{2}$ small bar. Table 4 summarizes the opening hours, schedule of the people and machines inside the bar. The assumed machines installed inside the bar are an induction cooking professional plate, a coffee machine, a professional cooling table, an ice machine and a fryer. The five soccer fields are equipped with 48 lights of $200 \mathrm{~W}$ (Table 4), switched on during the same bar opening hours. Note that lights are turned on as a function of the solar radiation availability after 18:00 during summer and after 16:00 during winter. The soccer fields also include locker rooms, where the people may change and have a shower. In particular, the amount of DHW for the locker rooms showers is assumed to be equal to 30,204 1/day (Table 4).

Figure 3 displays the power demand of the selected user. The spiky shape of the power demand curve (Figure 3) is mainly due to the fact that the selected user is a small bar. Thus, the user is not able to serve many consumers at the same time. Then, the electric appliances installed into the bar are intermittently used.

The heating season is assumed to be from November 15th to March 31st with an indoor setpoint temperature equal to $20^{\circ} \mathrm{C}$, while the cooling season is assumed to be from May 1st to September 30th with an indoor setpoint temperature equal to $26^{\circ} \mathrm{C}$, according to Italian regulation (Table 4).

Finally, the proposed system is equipped with an ESS based on the lithium-ion technology. The ESS assumed for this model is the Renault Zoe ZE nickel manganese cobalt oxide (NMC) lithium-ion 
battery (LIB) [23], consisting of 63.35 Ah rated capacity cells [23]. In particular, the rated capacity of the battery is $45.56 \mathrm{kWh}$, while the rated voltage is $360 \mathrm{~V}$ (Table 3). Table 5 reports the assumptions made for the thermoeconomic analysis.

\section{Results and Discussion}

In this section, the results achieved by means of the dynamic simulation models of both renewable plant (Case ETC and Case PV) are presented. In particular, the dynamic, monthly and yearly results are displayed. Moreover, a parametric analysis is shown by varying the lithium-ion storage system capacity, and the PV and ETC solar field area.

\subsection{Daily Results}

Figure 4 displays the transient results for Case ETC and Case PV, above and below, respectively. In particular, Figure 4 plots the power produced by ORC $\left(P_{e l, O R C}\right)$, the electric load of the proposed layout $\left(P_{e l, L O A D}\right)$, the power sent and withdrawn to/from the grid $\left(P_{e l \text { fromGRID }} P_{e l, t o G R I D}\right)$, the power sent/withdrawn to/from LIB $\left(P_{\text {el,fromLIB }} P_{\text {el,toLIB }}\right)$, the state of charge of the LIB battery $\left(S o C_{L I B}\right)$ and the power produced by the $\mathrm{PV}$ panels $\left(P_{e l, P V}\right)$.

For Case ETC, $S o C_{L I B}$ achieves its maximum value equal to 0.76 at 11:47, in fact, at this hour the load of the bar hugely increases, by reaching the value of $25.18 \mathrm{~kW}$, due to the activation of the induction cooking plate (Figure 4, above). Consequently, LIB is discharged, from 11.45 to 14:31 by matching the electric load of the bar, along with the power produced by the ORC machine. Note that the residual electric load, defined as $P_{e l, \text { residual }}=P_{e l, L O A D}-P_{e l, O R C}$, is greater than the maximum allowed discharging power $\left(P_{\text {LIB, dicharge,max }}\right)$, which is equal to $10 \mathrm{~kW}$ (Table 2$)$. Therefore, the power discharged from LIB is equal to $P_{\text {LIB,discharge,max }}$ and a rate of power equal to $P_{\text {el, residual }}-P_{\text {el, fromLIB }}$ is withdrawn from the grid (Figure 4, above). From 14:40 to 18:05 $P_{e l, L O A D}$ decreases, while $P_{e l, O R C}$ remains almost constant, consequently, $S o C_{L I B}$ grows up from 0.40 to 0.53. Anyway, at 18:05 the increase of the bar activity and the turning on of the soccer field lights causes a dramatical growth in $P_{e l, L O A D}$, reaching $38.47 \mathrm{~kW}$. Consequently, LIB is totally discharged in $2 \mathrm{~h}$, and from 20:05 the load of the system is completely satisfied by the grid and ORC machine. The power produced by the ORC is averagely equal to $5.5 \mathrm{~kW}$ over the day (Figure 4, above).

For Case PV, So $C_{L I B}$ achieves the high limit, equal to 0.95 (Table 2), at 10:00, when the PV field power production increases (Figure 4, below). In fact, during the daylight hours, the photovoltaic power production contributes significantly to charge the battery by matching a larger amount of the system electric load. The surplus power is supplied to the grid, with a power value equal to $5.72 \mathrm{~kW}$. When the bar activity increases, from 11.45 to 14:31, the ORC and PV production and LIB discharging supply the electric load of the bar. However, at 14:31 So $C_{L I B}$ rises again, because the overall electric production is higher than $P_{e l, L O A D}$. Finally, at 18:05 when $P_{e l, L O A D}$ hugely increases, as explained before, LIB is discharged and it is able to supply the system for $3 \mathrm{~h}$. Anyway, during this period $P_{e l \text {,fromGRID }}$ is not null, indeed, $P_{e l, \text { residual }}=P_{e l, L O A D}-P_{e l, O R C}-P_{e l, P V}$ is greater than $P_{L I B, \text { dicharge,max }}$ (Table 2). Therefore, as explained before, $P_{\text {ellfromLIB }}$ is fixed to $10 \mathrm{~kW}$ and the remaining amount of power, i.e., $P_{\text {el, residual }}-P_{\text {el, fromLIB }}$, is withdrawn from the grid. Finally, from 21:45 the system is completely supplied by the grid and ORC machine. Obviously, the total electric production, sum of the ORC and PV production significantly increases in the middle of the day, by achieving the maximum value of $11.17 \mathrm{~kW}$, due to the growth of the solar power production in these hours.

In conclusion, from Figure 4 it is clear that Case PV with respect to Case ETC produces a larger amount of power, consequently, the electric energy stored in the battery is greater. Thus, in the PV Case, LIB is able to cover a larger amount of the electric load of the system.

In Figure 5, the inlet oil temperature to the ORC evaporator $\left(T_{t o E V}\right)$ for typical summer and winter days are displayed. It is obvious that higher values of $T_{t o E V}$ are obtained in Case ETC. Obviously, the higher temperatures are reached in the middle of the day when the solar radiation is higher (the maximum value is $101.1^{\circ} \mathrm{C}$ at $\left.11: 45\right)$. Conversely, for Case $\mathrm{PV}, T_{t o E V}$ is averagely equal to $90-91{ }^{\circ} \mathrm{C}$ 
during winter and summer (Figure 5) days. Anyway, during the remaining part of the day, when the solar radiation is very low or absent there are no difference between the inlet oil temperatures in ETC and PV layouts.
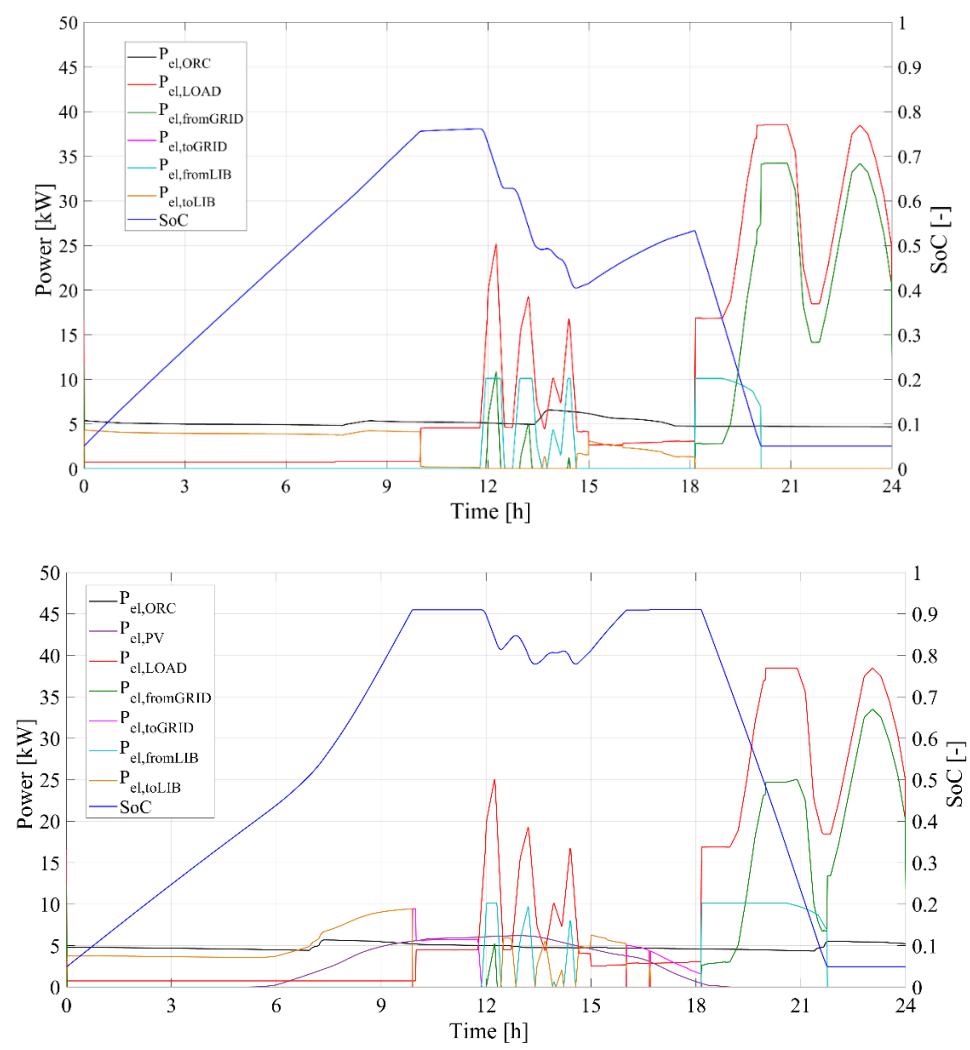

Figure 4. Dynamic results, typical summer working day: Case ETC (above) and Case PV (below).

\subsection{Monthly Results}

In this section, the monthly results for Case ETC and Case PV are reported. Figure 6 displays the ratios of the electric energy (i) produced by ORC $E_{e l, O R C}$, (ii) self-consumed $E_{e l, s e l f}$; (iii) withdrawn from

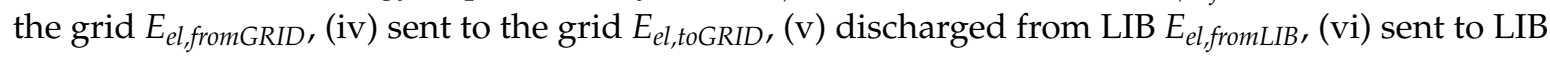
$E_{e l, t o L I B}$ and (vii) produced by PV $E_{e l, P V}$ on the monthly electric load of the studied layout $\left(E_{e l, L O A D}\right)$. The total produced amount of renewable electric energy (for Case PV) $E_{e l, \text { renw }}$ is also displayed.
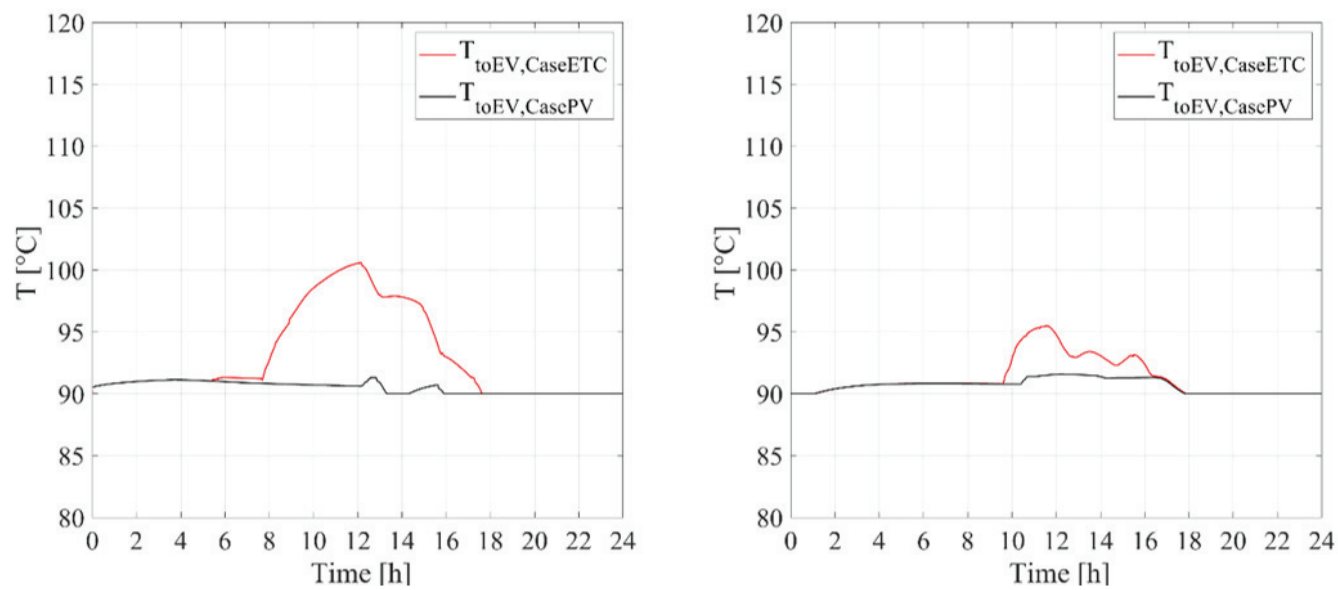

Figure 5. Feeding temperature of the evaporator of ORC: a typical summer day (left) and a typical winter day (right). 

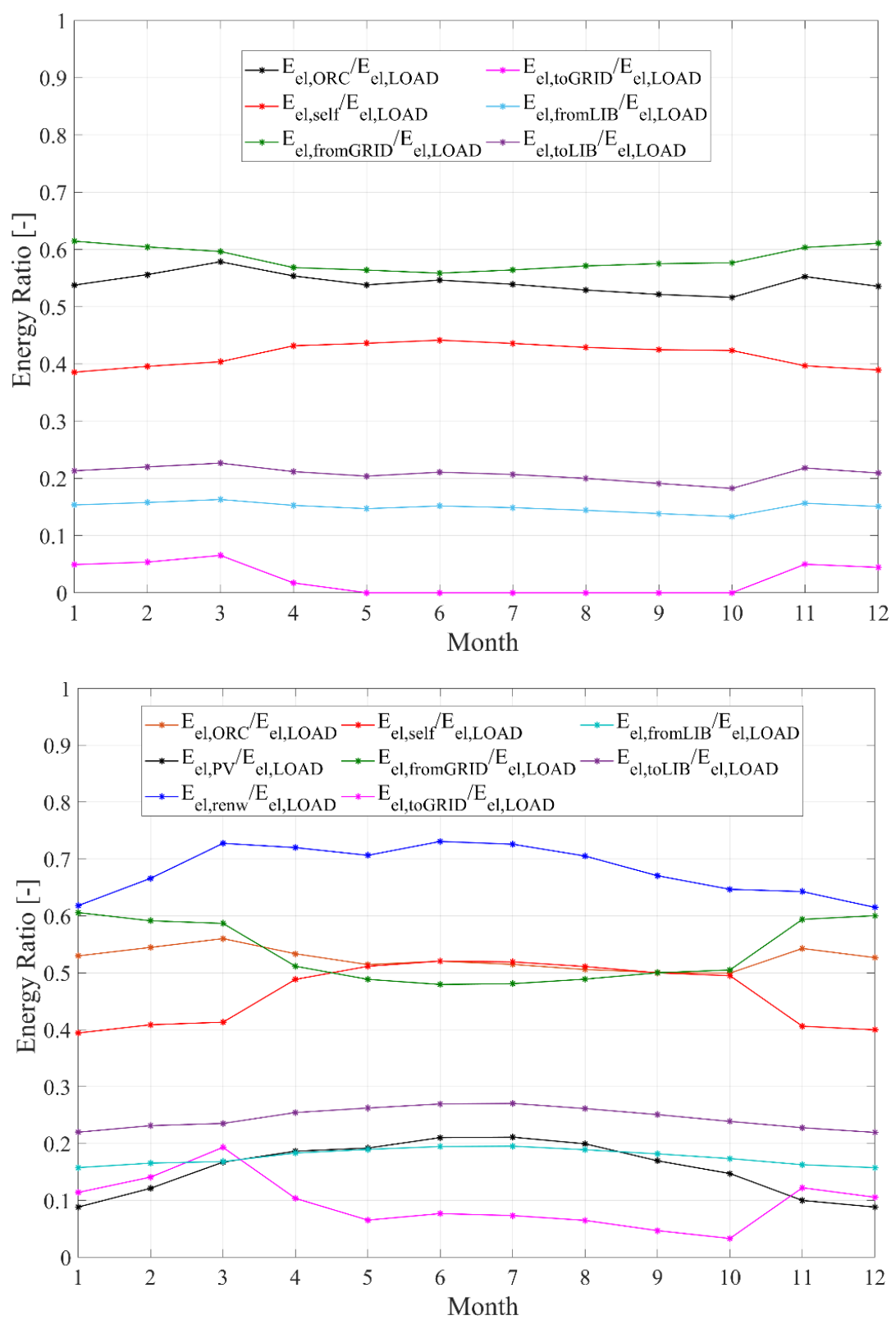

Figure 6. Monthly results, electric performance: Case ETC (above) and Case PV (below).

Case ETC does not achieve the energy self-sufficiency, indeed the ratio $E_{e l, s e l} / E_{e l, L O A D}$ constantly is lower than about $45 \%$ for all months of the year. LIB is able to cover about $14 \%-16 \%$ of the electric energy demand of the system. Note that LIB adoption causes the absence of surplus electric energy sent to the grid during the summer season (May-October), while during the remaining part of the year the $E_{e l, t o G R I D}$ ratio is lower than $6.7 \%$ (Figure 6, above).

Although Case PV achieves self-consumed energy ratios $E_{\text {el, self }} / E_{e l, L O A D}$ higher than Case ETC, ranging from $40 \%$ to $52 \%$, the energy self-sufficiency is not reached (Figure 6, below).

Note that the electric energy produced by the renewable sources (by PV and ORC) achieves higher values during the summer season due to the higher energy production by the PV field during the months of higher solar radiation. In fact, during the months of July and August $E_{e l, \text { renzo }} / E_{e l, L O A D}$ is equal to about $73 \%$. Moreover, during these months (July and August) the proposed plant (Case PV) reaches the higher value of self-consumed energy, i.e., $E_{e l, s e l f} / E_{e l, L O A D}$ equal to $52 \%$ and a lower value of electric energy withdrawn from the grid, i.e., $E_{e l, f r o m G R I D} / E_{e l, L O A D}$ equal to $48 \%$ (Figure 6 , below). 
The adoption of PV panels instead of ETCs leads to a significant increase in the electric energy produced by the proposed renewable plant. However, this higher electric energy production is not fully self-consumed by the user, in fact, Case PV exhibits a limited increase in $E_{e l, s e l f}$, because the electric energy demand is not simultaneous with the electric energy production, mainly because the electric load is concentered mainly in a few hours of the day (evening hours). In addition, the battery (LIB) is not able to store all the surplus electric energy, that is delivered to the grid, see $E_{e l, t o G R I D} / E_{e l, L O A D}$ ratio in Figure 6. Therefore, it is possible to conclude that the energy self-sufficiency is not reached in both plants.

Figure 7 shows, for both ETC and PV Cases, the thermal energy supplied to the ORC evaporator ( $Q_{t o E V, C a s e E T C}$ and $\left.Q_{t o E V, C a s e P V}\right)$, the electric energy produced by the ORC machine ( $E_{e l, O R C, C a s e E T C}$ and $\left.E_{e l, O R C, C a s e P V}\right)$ and the efficiency of the ORC machine ( $\eta_{O R C, C a s e E T C}$ and $\left.\eta_{O R C, C a s e P V}\right)$.
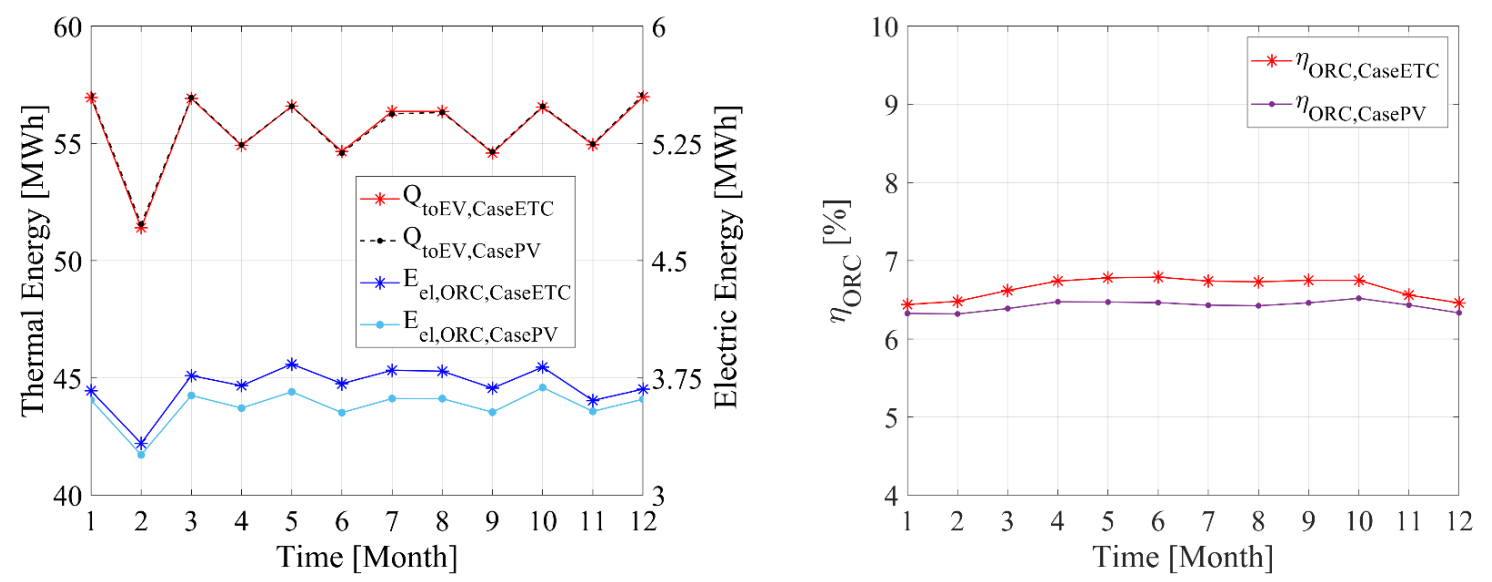

Figure 7. ORC performance: energy performance (left) and efficiency (right).

The thermal energy supplied to the ORC evaporator is about the same for both cases. The efficiencies are also similar but $\eta_{O R C, C a s e E T C}$ is slightly higher than $\eta_{O R C, C a s e P V}, 6.7 \%$ vs $6.4 \%$. This is due to the fact that the ORC inlet oil temperature is averagely higher in Case ETC than in Case PV (see Section 5.1 (Figure 5).

Figure 8 plots the ratios calculated by the following equations:

$$
R_{i}=\frac{Q_{i}}{Q_{\text {toEV }}}=\frac{Q_{i}}{Q_{\text {solar }}+Q_{\text {geoth }}+Q_{\text {biomass }}}
$$

where $Q_{\text {geoth }}$ is the geothermal energy provided to the ORC evaporator by means of HE1 and HE2, $Q_{\text {solar }}$ is the solar thermal energy provided by ETCs to the ORC evaporator and $Q_{\text {biomass }}$ is the thermal energy provided by $\mathrm{AH}$ to the ORC evaporator when the solar tank top temperature is lower than $90^{\circ} \mathrm{C}$ (Table 2). In Case PV, the geothermal source provides almost the total amount of thermal energy for driving the ORC machine and reduces slightly in Case ETC due to the solar thermal energy production. Indeed, in Case ETC $R_{\text {solar }}$ achieves the maximum value of $5.11 \%$, while $R_{\text {biomass }}$ is lower than $1.1 \%$. Without ETCs, $R_{\text {biomass }}$ does not significantly increase and achieves the maximum value of $1.73 \%$. Thus, in Case PV, the geothermal source supplies more than $98 \%$ of the thermal energy needed for the ORC (Figure 8).

In both investigated cases, the slight reduction of $R_{\text {geoth }}$ during the summer months (Figure 8), is due to the control strategy of the proposed system. In particular, during the summer season, the geothermal energy is used to supply the $\mathrm{ACH}$ producing the building space cooling, by reducing the geothermal energy sent to the ORC evaporator. In both plants, the biomass auxiliary heater could be removed without affecting significantly the overall plant performance. 

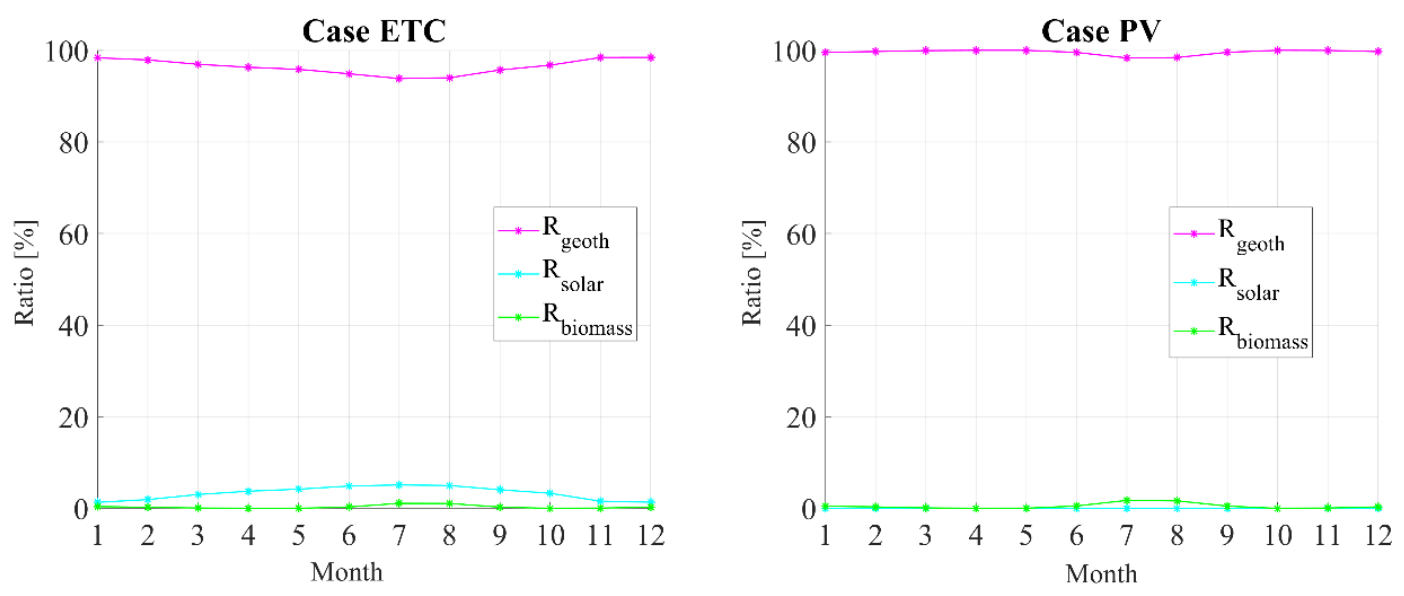

Figure 8. ORC evaporator energy ratios: Case ETC (left) and Case PV (right).

Figure 9 displays the thermal performance of the ground heat exchangers used to cool the condenser of ORC and ACH. In particular, in this figure, the thermal energy transferred from HE5 $\left(Q_{H E 5}\right)$ and HE6 $\left(Q_{H E 6}\right)$ to the ground for both the cases studied are represented. As mentioned before, the use of PV panels vs ETCs shows minor effects on ORC operation, and consequently, the thermal energy transferred from the ORC condenser to the ground is about the same for both the cases (Figure 9). $\mathrm{ACH}$ operates in the same way both in Case ETC and in Case PV, consequently, the values of $Q_{H E 5}$ are about similar (Figure 9). Anyway, the maximum values of energy transferred to the ground occur during the summer months, when the thermal energy required for the building space cooling increases. In fact, during the months of July and August $Q_{H E 5}$ achieves the values of $10.7 \mathrm{MWh}$ and $10.3 \mathrm{MWh}$, for both cases (Cases ETC and PV, Figure 9).

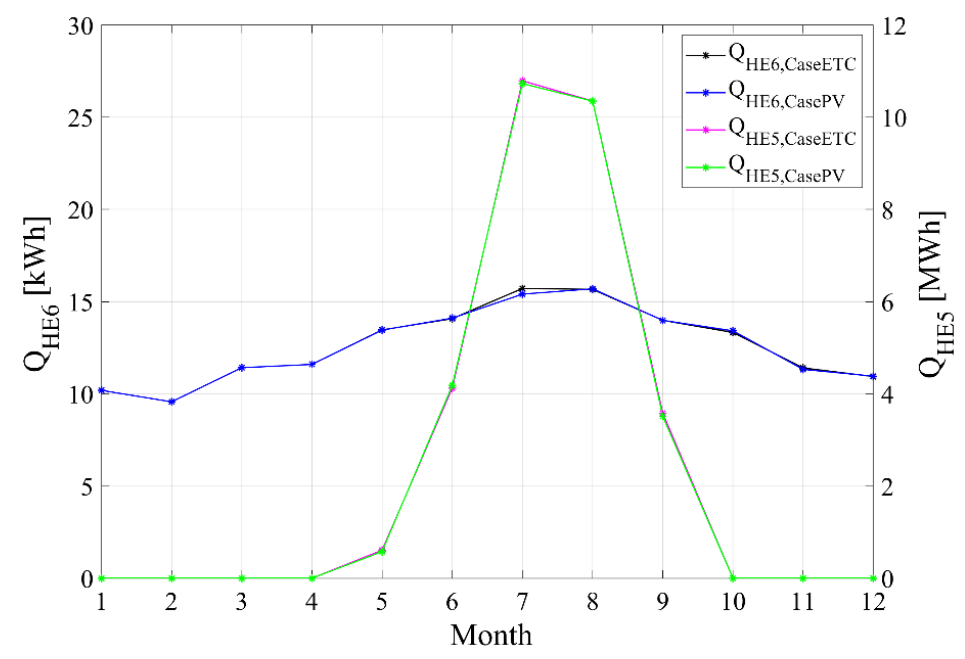

Figure 9. Ground heat exchanger energy performance.

\subsection{Yearly Results}

Considering the previously discussed results, the yearly thermo-economic and environmental results of the studied cases are discussed in Tables 6 and 7. The adoption of PV panels leads to a greater production of electric energy, in fact $E_{\text {el,prod,CasePV }}$ is equal to $55.77 \mathrm{MWh} / \mathrm{year}$, whereas

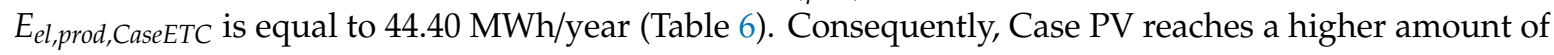
self-consumed energy. Therefore, Case PV achieves a higher PES than Case ETC, $51.21 \%$ vs $37.81 \%$ (Table 7). The avoided equivalent $\mathrm{CO}_{2}$ emissions obviously follow the same trend of $P E S$ (Table 7). 
Table 6. Energy yearly results.

\begin{tabular}{cccccc}
\hline Case & $\begin{array}{c}E_{\text {el, ORC }} \\
{[\mathrm{MWh} / \text { Year] }}\end{array}$ & $\begin{array}{c}E_{\text {el,PV }} \\
{[\mathrm{MWh} / \text { Year] }}\end{array}$ & $\begin{array}{c}E_{\text {el,prod }} \\
\text { [MWh/year] }\end{array}$ & $\begin{array}{c}E_{\text {el,fromGRID }} \\
{[\text { [MWh/Year] }}\end{array}$ & $\begin{array}{c}E_{\text {el,toGRID }} \\
\text { [MWh/Year] }\end{array}$ \\
\hline ETC & 44.40 & - & 44.40 & 47.85 & 1.83 \\
\hline PV & 42.86 & 12.91 & 55.77 & 43.74 & 7.63 \\
\hline
\end{tabular}

Table 7. Yearly energy, economic and enviromental results.

\begin{tabular}{ccccccccc}
\hline Case & $\begin{array}{c}\Delta P E \\
{[\mathbf{M W h} / \text { Years }]}\end{array}$ & $\begin{array}{c}P E S \\
{[\%]}\end{array}$ & $\begin{array}{c}\text { SPB } \\
{[\text { Years] }}\end{array}$ & $\begin{array}{c}S P B_{\text {inc }} \\
{[\text { Years] }}\end{array}$ & $\begin{array}{c}J_{\text {tot }} \\
{[\mathbf{k}]}\end{array}$ & $\begin{array}{c}\Delta C \\
{[\mathbf{k} / \text { Year }]}\end{array}$ & $\begin{array}{c}\Delta C \mathrm{O}_{2} \\
{[\mathbf{t} / \text { Year] }]}\end{array}$ & $\begin{array}{c}\Delta \mathrm{CO}_{2} \\
{[\%]}\end{array}$ \\
\hline ETC & 60.94 & 37.81 & 14.71 & 7.36 & 111.64 & 7.59 & 13.37 & 37.70 \\
\hline PV & 82.40 & 51.21 & 12.56 & 6.28 & 109.62 & 8.73 & 18.13 & 51.13 \\
\hline
\end{tabular}

In conclusion from and energy and environmental point of view, Case PV exhibits better performance.

From an economic point of view, Case PV achieves a better SPB with respect to Case ETC. This result is mainly due to the higher electric energy produced, self-consumed and sold to the grid in Case PV. Note as $E_{\text {el,toGRID }}$ is equal to $1.83 \mathrm{MWh} /$ year and $7.63 \mathrm{MWh} /$ year for Cases ETC and PV, respectively (Table 6). Therefore, the yearly economic saving for Case ETC (7.59 k€/year) is lower than the one obtained for Case PV ( $8.73 \mathrm{k} € /$ year), while the total capital costs of both cases are about similar

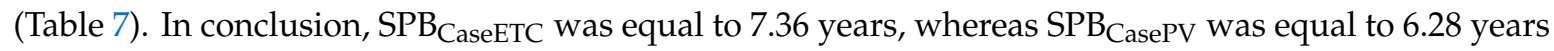
(Table 7).

Table 8 shows the performance indexes of the studied cases. For Case ETC, the solar thermal energy meets about $3 \%$ of the thermal energy delivered to the ORC, i.e., $R_{\text {solar }}$ equal to $3.24 \%$. $R_{\text {biomass }}$ passes from $0.31 \%$ for Case ETC to $0.42 \%$ for Case PV (Table 8 ). Thus, the absence of ETCs determines minor variations in the ORC electricity production. Anyway, the absence of ETC causes a lower inlet oil temperature to the ORC evaporator and consequently, ORC efficiency is slightly lower in Case PV, $6.45 \%$ vs $6.70 \%$ in Case ETC. Note that the value of the efficiency achieved by both the analyzed layouts (Case ETC and Case PV) is consistent with the values available in the literature [32]. For the reason above explained, the electric energy produced by ORC is slightly lower in Case PV, $42.86 \mathrm{MWh} /$ year vs 44.40 MWh/year in Case ETC (Table 6). This difference does not affect the overall performance of Case $\mathrm{PV}$, exhibiting better results from energy, environmental and economic points of view.

Table 8. Yearly performance index.

\begin{tabular}{cccccccc}
\hline Case & $\begin{array}{c}\boldsymbol{R}_{\text {solar }} \\
{[\%]}\end{array}$ & $\begin{array}{c}\boldsymbol{R}_{\text {geoth }} \\
{[\%]}\end{array}$ & $\begin{array}{c}\boldsymbol{R}_{\text {biomass }} \\
{[\%]}\end{array}$ & $\begin{array}{c}\text { COP } \\
{[-]}\end{array}$ & $\begin{array}{c}\eta_{\text {ORC }} \\
{[\%]}\end{array}$ & $\begin{array}{c}\eta_{\text {solar }} \\
{[\%]}\end{array}$ & $\begin{array}{c}m_{\text {biomass }} \\
{[\mathbf{6 g}]}\end{array}$ \\
\hline ETC & 3.24 & 96.45 & 0.31 & 0.74 & 6.65 & 50.46 & 596.90 \\
\hline PV & - & 99.58 & 0.42 & 0.74 & 6.42 & 15.43 & 906.38 \\
\hline
\end{tabular}

Finally, the yearly COP of the ACH is also evaluated (Table 8). This value, equal to 0.74 , is similar to the results available in literature about the performance of single-stage $\mathrm{LiBr} / \mathrm{H}_{2} \mathrm{O} \mathrm{ACH}$ [33]. Note that the achieved COP of 0.74 is slightly higher than the rated value, due to the high activation temperature of the geothermal brine.

\subsubsection{Parametric Analysis}

A parametric analysis is carried out with the aim of analyzing the effects of the variability of LIB capacity and of ETC and PV area on the energy, economic and environmental performance. 


\subsubsection{Battery Capacity}

By taking into account the proposed renewable plants, LIB capacity varied from $22.11 \mathrm{kWh}$ to $227.77 \mathrm{kWh}$. Figure 10 displays the energy and environmental result of the parametric analysis for each case (Case ETC and Case PV). In particular Figure 10 (left) displays PES and $\triangle \mathrm{CO}_{2}$, while Figure 10 (right) points out the ratios: (i) $E_{\text {elffromGRID }}$ on $E_{e l, L O A D}$, (ii) $E_{e l, t o G R I D}$ on $E_{e l, L O A D}$ and (iii) $E_{e l, s e l f}$ on $E_{e l, L O A D}$.
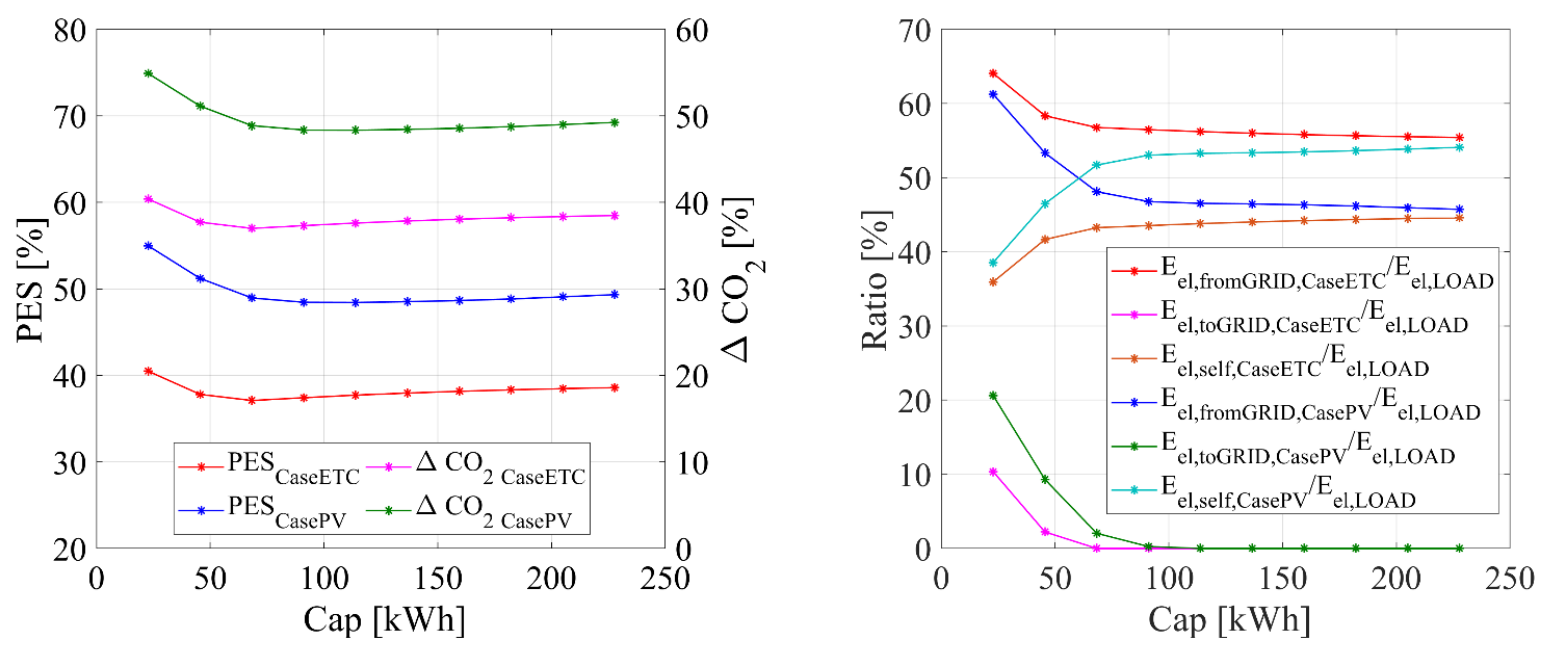

Figure 10. Parametric analysis: $P E S$ and $\triangle \mathrm{CO}_{2}$ (left) and energy ratios (right).

The increase in battery capacity from 22.11 to $227.77 \mathrm{kWh}$ causes a reduction in the energy performance: $P E S_{\text {CaseETC }}$ passes from $40.48 \%$ to $38.59 \%$ and $P E S_{\text {CasePV }}$ varies from $54.97 \%$ to $49.33 \%$ for Case PV. These trends are due to the battery discharge and charge efficiency. In fact, supplying the surplus electric energy to LIB and discharging the battery when needed, leads to a loss of electric energy, and therefore, a reduction of PESs (Figure 10). However, both the studied cases exhibit the same trend. In fact, after an initial decrease, the values of PES become almost constant by further increasing the battery capacity.

This behavior is well explained by Figure 10 (left), in fact, the $E_{e l, s e l f} / E_{e l, L O A D}$ ratio initially increases but for capacity values higher than $113.9 \mathrm{kWh}$, the ratio is almost constant, to almost $53 \%$ and $44.2 \%$ for Case PV and Case ETC, respectively (Figure 10). In order to obtain a further increase of the ratio $E_{e l, s e l f} / E_{e l, L O A D}$, an increase in the electric energy production by PV panels or ORC machine is needed because with the current installed electric capacity, the proposed renewable plant covers only $53 \%$ for Case PV and $44.2 \%$ for Case ETC of the total electric energy demand (Figure 10).

Besides, the increase of LIB capacity leads to a limited worsening of the energy and environmental performance, for both the analyzed cases.

In Figure 11 the economic results are shown, in particular, Figure 11 (left) displays SPB, while Figure 11 (right) displays $J_{\text {tot }}$ and $\Delta C$. Figure 10 (left) also explains the economic results: by increasing the battery capacity, the values of electric energy sent/withdrawn to/from the grid initially decreases/increases but for capacity values higher than $113.9 \mathrm{kWh}$ they become about constant (Figure 10). Consequently, the yearly economic savings initially increase and then become almost constant. In particular, for capacity values higher than $113.9 \mathrm{kWh}, \Delta C_{\text {CaseETC }}$ and $\Delta C_{\text {CasePV }}$ are equal to about $7.8 \mathrm{k} € /$ year and to about $9.1 \mathrm{k} € /$ year, respectively (Figure 11). By increasing the battery capacity from $22.11 \mathrm{kWh}$ to $227.77 \mathrm{kWh}$, the capital cost hugely increases from $103.7 \mathrm{k} €$ and $101.7 \mathrm{k} €$ to $174.7 \mathrm{k} €$ and $172.7 \mathrm{k} €$, for Case ETC and Case PV, respectively. This is mainly due to the high cost of LIB.

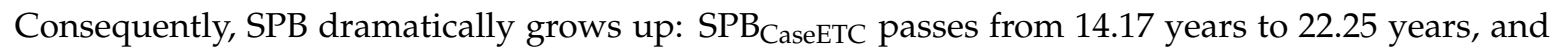
$P B_{\text {CasePV }}$ varies from 12.17 years to 18.82 years. 

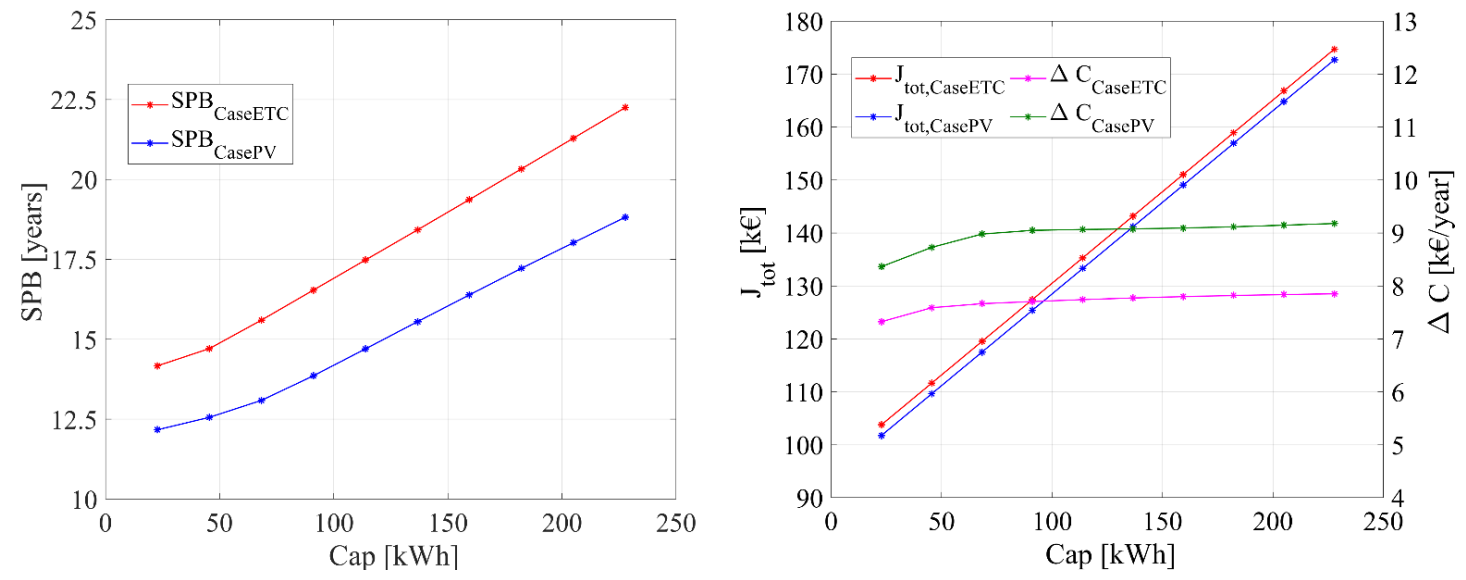

Figure 11. Parametric analysis: SPB (left) and capital cost and economic savings (right).

In conclusion, the LIB capacity increase causes a general reduction in the economic performance of the two studied cases.

\subsubsection{PV and ETC Area}

The area of ETCs and PV panels varied from $5 \mathrm{~m}^{2}$ to $85 \mathrm{~m}^{2}$. The energy and environmental results of this parametric analysis are displayed in Figures 12 and 13. In particular, Figure 12 (left) displays the electric energy produced by the ORC and the ORC efficiency, for both the studied cases, while Figure 12 (right) shows the electric energy withdrawn/sent from/to the grid, and the total electric energy produced by the proposed renewable power plants. Figure 13 (left) displays PES and Figure 13 (right) shows $\triangle \mathrm{CO}_{2}$.
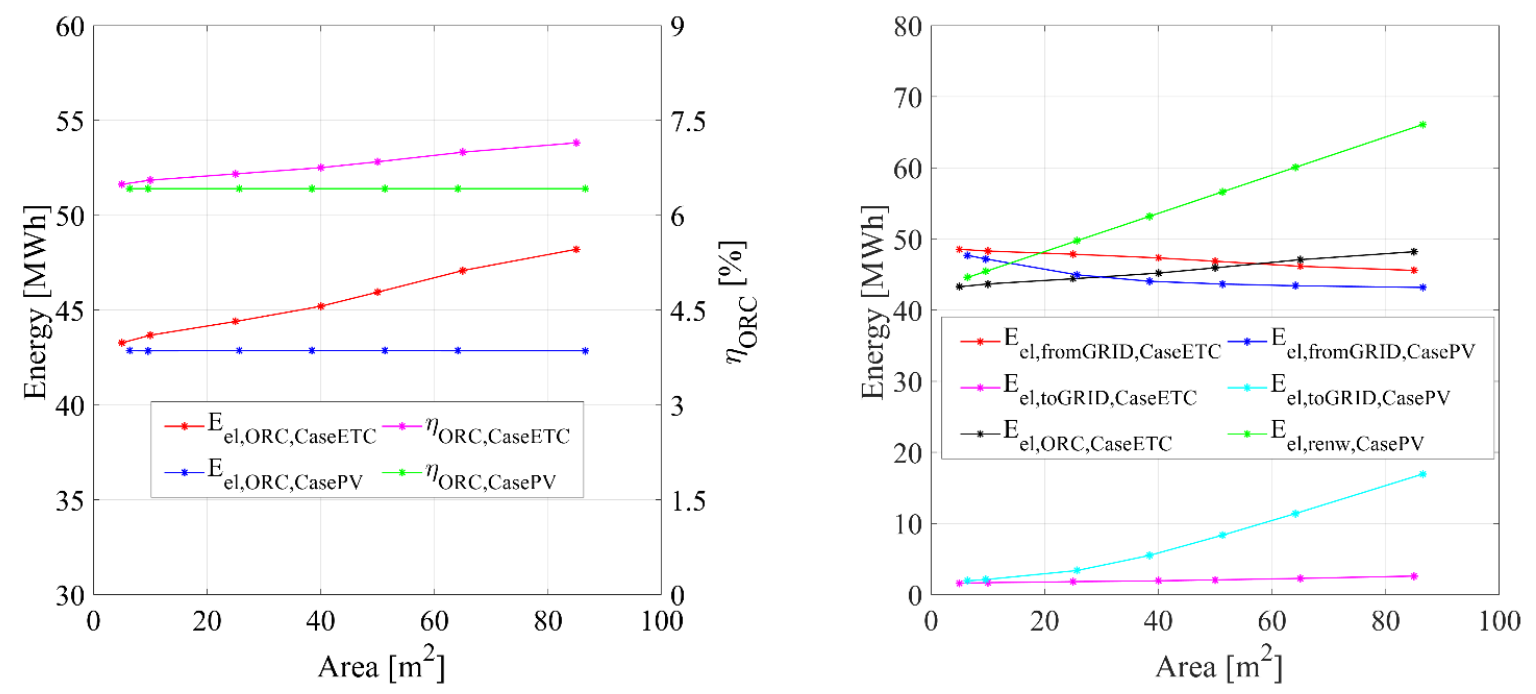

Figure 12. Parametric analysis: ORC performance (left) and electric energy performance (right).

The increase of ETCs area directly affects the ORC performance: the higher the ETCs area the higher the thermal energy provided to the ORC evaporator, and consequently, the higher the electric energy produced by the ORC. Conversely, the variation of PV field area obviously does not affect the ORC performance. Thus $E_{e l, O R C, C a s e E T C}$ increases, by passing from $43.28 \mathrm{MWh} /$ year to $48.21 \mathrm{MWh} /$ year, while $E_{e l, O R C, C a s e P V}$ remains constant (Figure 12).

Note that the growth of the ETCs area causes also an increase of $\eta_{O R C}$, because for higher ETCs areas, higher inlet oil temperatures to the ORC evaporator are reached. In particular, $\eta_{\text {ORC,CaseETC }}$ passes from $6.49 \%$ to $7.15 \%$, by varying ETCs area from $5 \mathrm{~m}^{2}$ to $85 \mathrm{~m}^{2}$ (Figure 12). 
Anyway, by considering the whole plant, the increase of PV field area with respect to the increase of ETCs area leads to a more significant enhancement of the energy performance of the power plant. In fact, the increase of the PV field causes a remarkable increase in the electric energy production, due to PV field energy production, thus $E_{\text {el, renw }}$ passes from $44.58 \mathrm{MWh} /$ year to $66.09 \mathrm{MWh} /$ year (Figure 12). This result affects the values obtained for $E_{e l, t o G R I D, C a s e P V}$, significantly increasing from $1.96 \mathrm{MWh} /$ year to $16.96 \mathrm{MWh} /$ year (Figure 12).

Note that, although the electric energy production for Case PV significantly increases, the electric energy withdrawn from the grid exhibits a limited reduction. This is due to the selected LIB capacity (that is not able to store all the electric energy surplus), and because the electric load and production are not simultaneous. For all the reasons above explained, $P E S_{C a s e E T C}$ values increase slightly, whereas $P E S_{\text {CasePV }}$ values increase remarkably. In particular, $P E S_{\text {CaseETC }}$ and $P E S_{\text {CasePV, }}$, respectively, passes from $36.89 \%$ and $38.19 \%$ to $41.94 \%$ and $64.57 \%$ (Figure 13). The avoided $\mathrm{CO}_{2}$ emissions follow the same trend as PES. Finally, the increase of the solar fields area enhances the energy and environmental performance of the proposed plants.
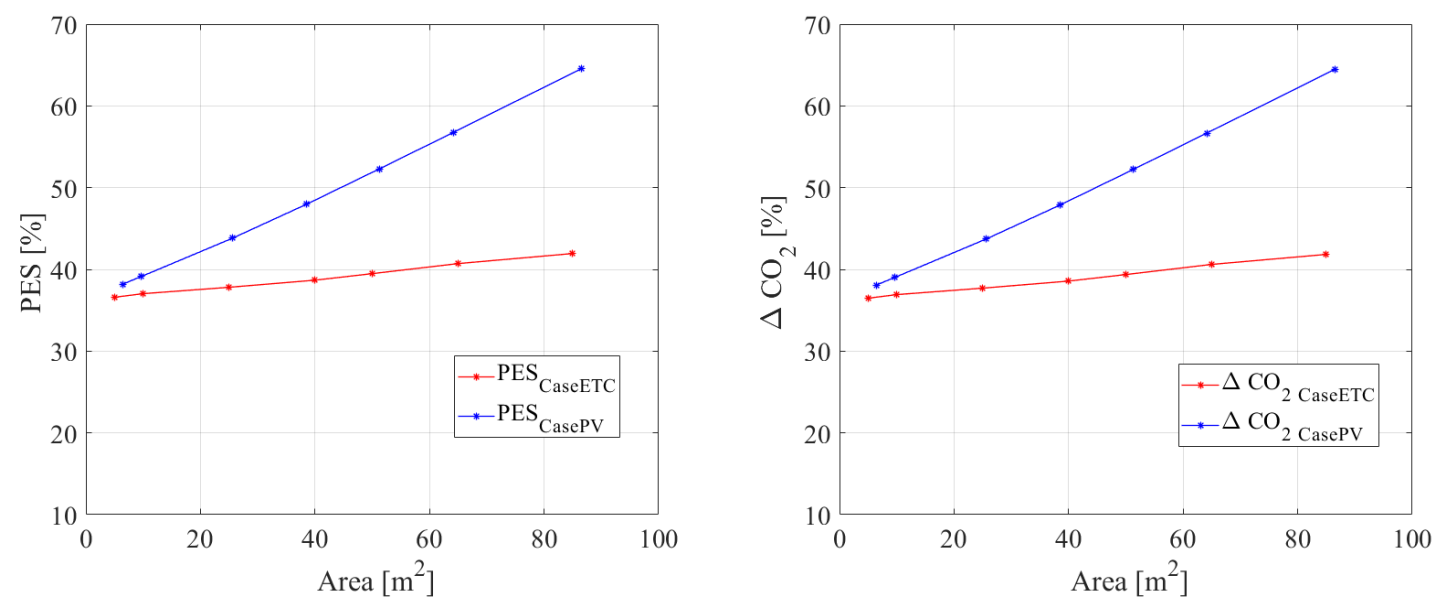

Figure 13. Parametric analysis: PES (left) and avoided equivalent $\mathrm{CO}_{2}$ emissions (right).

Figure 14 displays the economic results, in particular this figure plots SPB (left) and $J_{t o t}$ and $\triangle C$ (right). $E_{\text {elffromGRID,CaseETC }}$ exhibits a limited reduction without significative increasing of $E_{e l, t o G R I D, C a s e E T C,}$ whereas $E_{\text {el,fromGRID,CasePV }}$ exhibits a limited reduction but a remarkable increase in $E_{e l, t o G R I D, C a s e P V}$. Therefore, $\Delta C_{\text {CaseETC }}$ remains about constant, conversely, $\Delta C_{\text {CasePV }}$ increases. In fact, $\Delta C_{\text {CaseETC }}$ is averagely equal to about $7.73 \mathrm{k} € /$ year, whereas $\Delta C_{\text {Case } P V}$ passes from $7.73 \mathrm{k} € /$ year to $9.44 \mathrm{k} € /$ year. The capital cost of both the cases has a remarkable increase but $J_{\text {tot,CaseETC }}$ is higher than $J_{t o t, C a s e P V}$ due to the higher capital cost of evacuated thermal solar collectors with respect to the PV panels.

Therefore, $\mathrm{SPB}_{\text {CaseETC }}$ increases by passing from 13.69 years to 16.91 years. Conversely, $\mathrm{SPB}$ CasePV shows a limited decrease, by passing from 13.30 years to 12.27 years.

In conclusion, Case PV has better energy, environmental and economic performance. However, the increase of the ETCs and PV panels area leads to an enhancement of the energy and environmental performance of the proposed renewable power plans. Conversely, from the economic point of view, the better configuration suggests larger PV fields. 

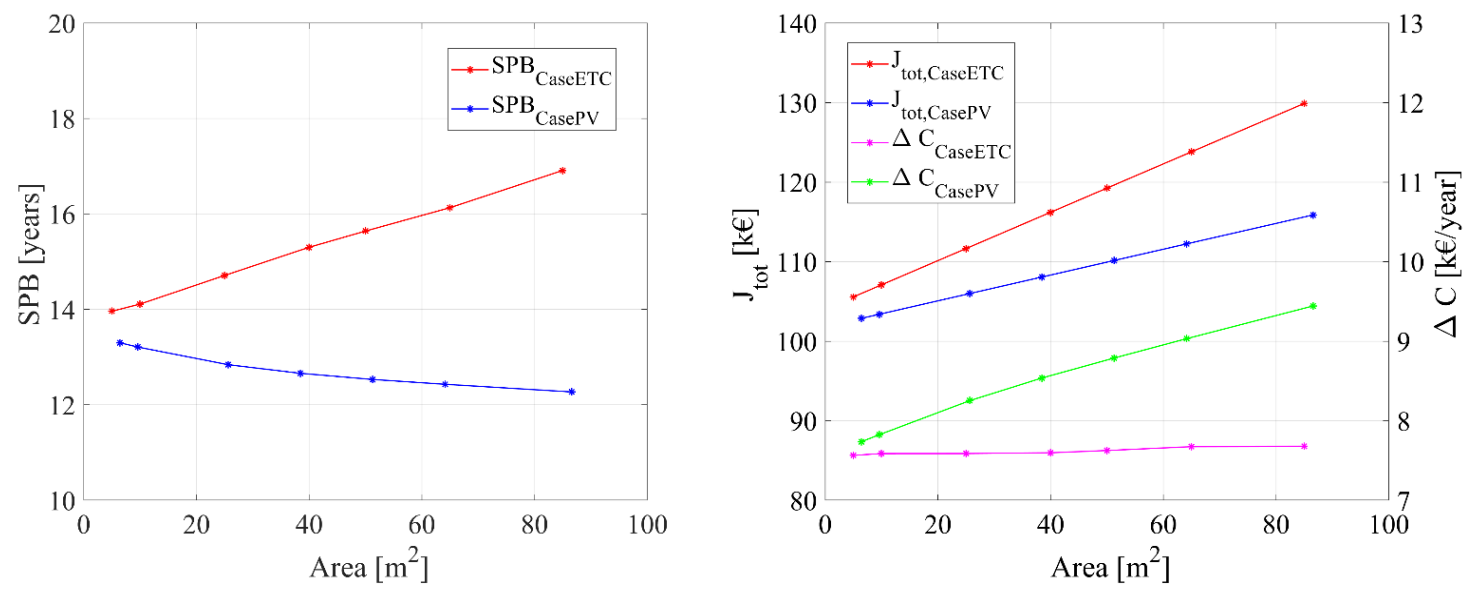

Figure 14. Parametric analysis: SPB (left) and capital and operative cost (right).

\subsubsection{Optimization}

In conclusion, an optimization analysis is performed in order to detect the optimal configuration of each analyzed layout. Primary energy savings, avoided $\mathrm{CO}_{2}$ emissions and simple payback period are considered as object functions. For PV layout, the number of battery cells in parallel and the size of the PV field are simultaneously varied (Table 9). The results of these simulations are displayed in Figure 15. The best configuration achieves a PES equal to $107 \%$, a $\Delta \mathrm{CO}_{2}$ equal to $107 \%$ and a SPB equal to 8.60 years. This configuration consists of a PV field area equal to $200 \mathrm{~m}^{2}$ and a storage system capacity equal to $22.78 \mathrm{kWh}$. This layout exhibits the larger PV field and the smaller battery capacity. This trend is due to the high cost of the lithium-ion battery. Indeed, increasing the battery size the economic performance worsens. Figure 15 (left) displays the Pareto front for two objective functions: SPB and PES. Note that the higher the primary energy savings, the lower the payback period. These configurations are that in which the PV field is larger, and the battery capacity is smaller.

Table 9. Parameter varied during the optimization analysis, PV layout and ETC playout.

\begin{tabular}{|c|c|c|c|c|c|c|}
\hline \multirow{3}{*}{ Case PV } & \multicolumn{3}{|c|}{ PV Area $\left[\mathrm{m}^{2}\right]$} & \multicolumn{3}{|c|}{ Battery Capacity [kWh] } \\
\hline & \multicolumn{2}{|c|}{$\min$} & $\max$ & $\min$ & & $\max$ \\
\hline & \multicolumn{2}{|c|}{5} & 200 & 22.78 & & 683.31 \\
\hline \multirow{3}{*}{ Case ETC } & \multicolumn{2}{|c|}{ ETC Area $\left[\mathrm{m}^{2}\right]$} & \multicolumn{2}{|c|}{ Battery Capacity [kWh] } & \multicolumn{2}{|c|}{ Specific Tank Parameter $\left[1 / \mathrm{m}^{2}\right]$} \\
\hline & $\min$ & $\max$ & $\min$ & $\max$ & $\min$ & $\max$ \\
\hline & 5 & 85 & 22.78 & 341.66 & 2.5 & 10 \\
\hline
\end{tabular}
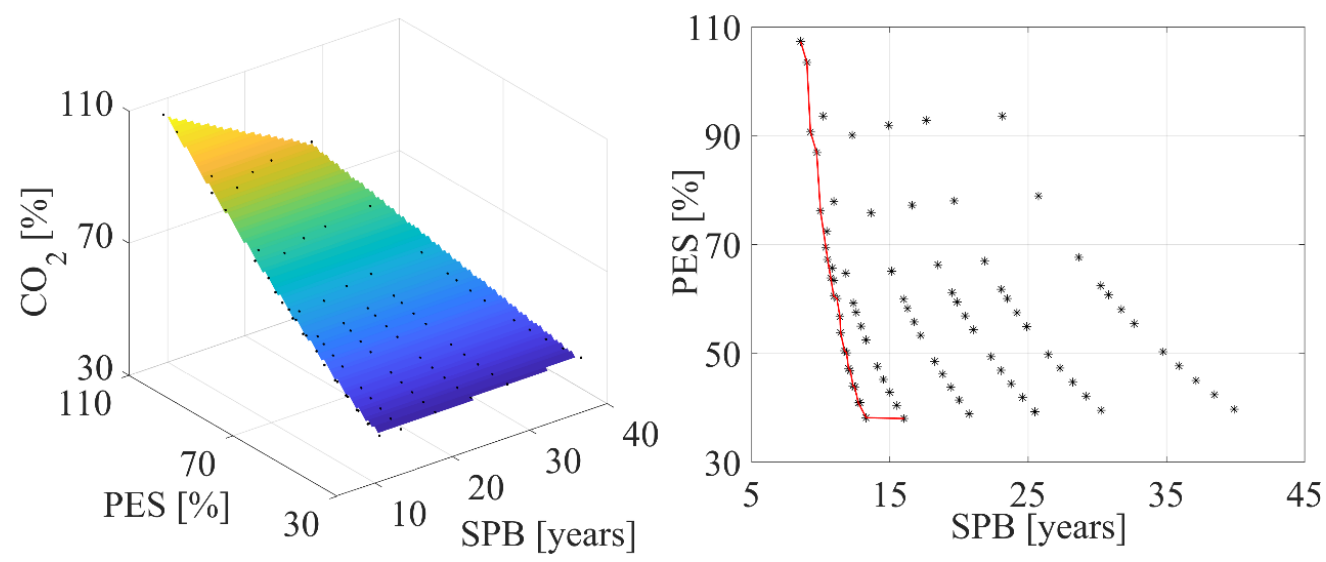

Figure 15. 2D Pareto frontier (left) and Optimal configuration research for Case PV (right). 
For ETC layout, the number of the battery cells in parallel, the size of the ETC field and the specific tank parameter are simultaneously varied (Table 9). It is clear that the increase of the avoided $\mathrm{CO}_{2}$ emissions and primary energy savings lead to a remarkable increase of the payback period, reducing the economic feasibility of the ETC layout (Figure 16). This trend is related to the high cost of the ETCs, indeed increasing the ETCs field area PES and $\triangle \mathrm{CO}_{2}$ increase while SPB worsens. Moreover, as deeply explained in the previous section, the increase in the ETC area leads to a not so significant improvement of the ORC efficiency. Therefore, the increase in the ETC area causes a huge rise in the capital cost and a limited increase in the yearly savings.
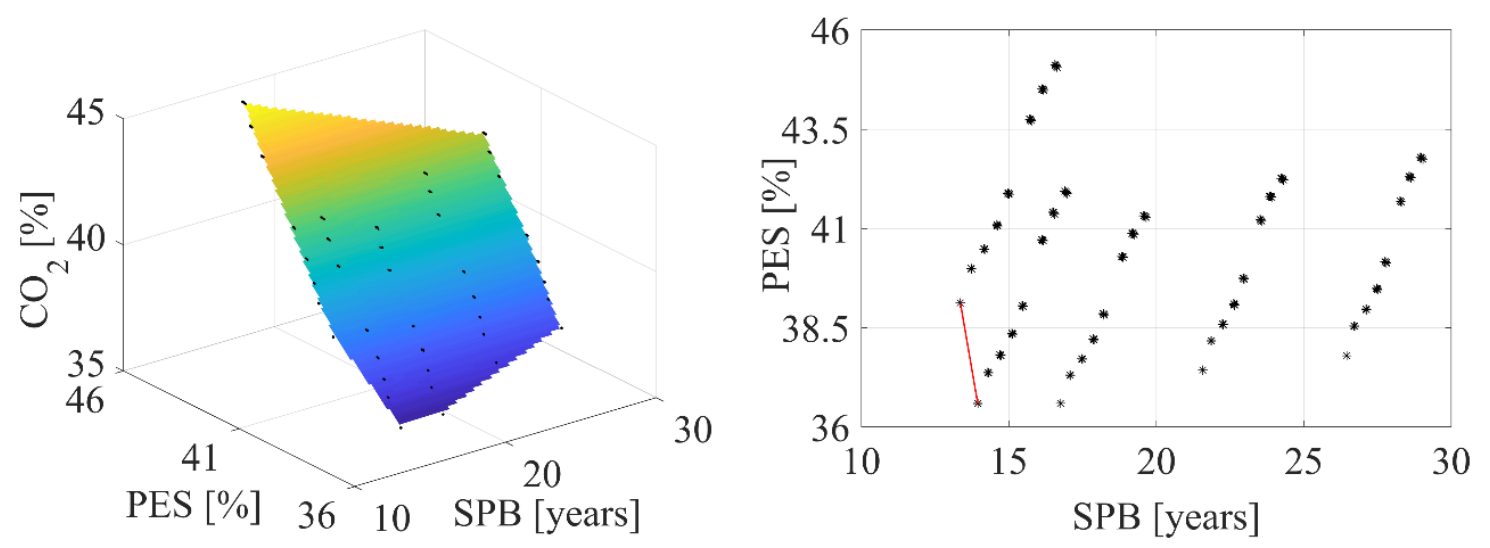

Figure 16. 2D Pareto frontier (left) and Optimal configuration research for Case ETC (right).

The optimal configuration, consisting of an ETC field equal to $5 \mathrm{~m}^{2}$, a specific tank parameter equal to $7.5 \mathrm{l} / \mathrm{m}^{2}$ and a battery capacity equal to $22.78 \mathrm{kWh}$, achieves a payback period of 13.36 years, a $\triangle \mathrm{CO}_{2}$ equal to $38.91 \%$ and a PES equal to $39.12 \%$ (Figure 16). Note that the system is not too sensitive to the variation of the specific tank parameter, in fact, the overlapped points (Figure 16) are due to the configurations among which varies only this parameter.

\section{Conclusions}

In this work, two innovative micro renewable polygeneration plants, both consisting of a micro organic Rankine cycle, single-stage $\mathrm{H}_{2} \mathrm{O} / \mathrm{LiBr}$ absorption chiller, geothermal well, biomass auxiliary heater and lithium-ion battery are presented. The main aim of this work is the thermoeconomic comparison of two alternative solar technologies integrated as auxiliary systems into two polygeneration plants, namely the evacuated solar collectors and photovoltaic panels. Both plants produce power for, heat and cool a small bar, located in Naples (South Italy), in a weather zone famous for its volcanic activity and high solar availability. Plant layouts are dynamically simulated in the TRNSYS environment, by developing comprehensive models suitable for evaluating the transient energy performance (temperatures, heat, power and efficiency) of all the plant components on hourly, daily, weekly, monthly and yearly time basis. A parametric analysis of the design parameters of the key units of the plant is also performed. The main findings of the simulations are summarised in the following:

- During the daylight hours, evacuated solar collectors rise the inlet oil temperatures to the organic Rankine cycle evaporator on average by of $5-10^{\circ} \mathrm{C}$ with respect to the plant including photovoltaic panels, consequently, a higher organic Rankine cycle efficiency, $6.7 \%$ vs $6.4 \%$, is obtained;

- The polygeneration plant including photovoltaic panels showed better performance from an energy, environmental and economic point of view with respect to the plant including evacuated solar collectors. In particular, the primary energy saving, payback period, and avoided $\mathrm{CO}_{2}$ emissions are $51 \%$ and $38 \%, 15$ years and 13 years and $51 \%$ and $38 \%$;

- The lithium-ion battery capacity increasing causes an increase in the energy-self-sufficiency but a worsening of the economic, energy and environmental performance of two studied plants; 
- From the economic point of view the better configuration suggests larger photovoltaic fields and smaller evacuated solar collectors fields due to the higher capital cost of evacuated solar collectors than photovoltaic panels and the achievable economic saving for the higher amount of selling electric energy.

Finally, an optimization analysis is carried out for both the analyzed layouts, the main findings are listed in the following:

- For the layout including photovoltaic panels (Case PV) the larger the photovoltaic field and the lower the battery capacity the better the energy, environmental and economic indices of the plant;

- For the layout including evacuated solar collectors (Case ETC) the tank size does not affect the performance of the plant;

- The optimal layout based on evacuated solar collectors (Case ETC) consists of the lower collector area and the lower battery capacity due to the high costs of both the battery and evacuated solar collector.

Author Contributions: Conceptualization, F.C., F.L.C., M.D.d. and M.V.; Methodology, F.C., F.L.C., M.D.d. and M.V.; Software, F.C., F.L.C., M.D.d. and M.V.; Writing-review and editing, F.C., F.L.C., M.D.d. and M.V. All authors have read and agreed to the published version of the manuscript.

Funding: It is important to stress that this work is developed in the framework of the project "GEOGRID", aiming at adopting suitable technologies and methods in order to use efficiently the geothermal energy of the Campania Region (South Italy). This project is funded by POR CAMPANIA FESR 2014/2020.

Conflicts of Interest: The authors declare no conflict of interest.

\section{Nomenclature}

A

$c$

$c_{p}$

$d$

$e$

$F_{S O C}$

G

$g$

h

I

J

k

$l$

LHV

m

m

$m_{\text {ORC }}$

$m_{S F}$

$N_{p}$

$N_{\text {pipe }}$

$N_{S}$

$P$

PE

PES

$Q$

$Q$

$Q_{m}$

$r$

R

area $\left(\mathrm{m}^{2}\right)$

specific cost-price $\left(€ / \mathrm{kWh}\right.$ or $€ / \mathrm{m}^{2}$ or $€ / \mathrm{m}$ or $\left.€ / \mathrm{t}\right)$

specific heat at constant pressure $\left(\mathrm{kJ} \mathrm{kg}^{-1} \mathrm{~K}^{-1}\right)$

pipe diameter $(\mathrm{m})$

open circuit voltages at full charge, extrapolated from V-I curve (V)

fractional state of charge (-)

incident solar total radiation $\left(\mathrm{W} \mathrm{m}^{-2}\right)$

small-valued coefficients of $\mathrm{H}$ in voltage-current-state of charge

formulas (V)

heat transfer coefficient $\left(\mathrm{W} \mathrm{m}{ }^{-2} \mathrm{~K}^{-1}\right)$

current (A)

capital cost $(€)$

conductibility $\left(\mathrm{W} \mathrm{m}^{-1} \mathrm{~K}^{-1}\right)$

length $(\mathrm{m})$

lower heating value $\left(\mathrm{kWh} \mathrm{Sm}^{-3}\right)$

mass flow rate $\left(\mathrm{kg} \mathrm{s}^{-1}\right)$

cell-type parameters for the shape of the I-V-Q characteristics (-)

ORC yearly maintenance (\%/year)

solar field yearly maintenance (\%/year)

number of modules in parallel (-)

number of pipe (-)

number of modules in series (-)

electric power $(\mathrm{kW})$

primary energy $(\mathrm{kWh} /$ year $)$

primary energy saving (-)

thermal power $(\mathrm{kW})$

electric charge (Ah)

rated capacity of cell (Ah)

internal resistances at full charge $(\Omega)$

thermal resistance $\left(\mathrm{k} \mathrm{W}^{-1}\right)$ 


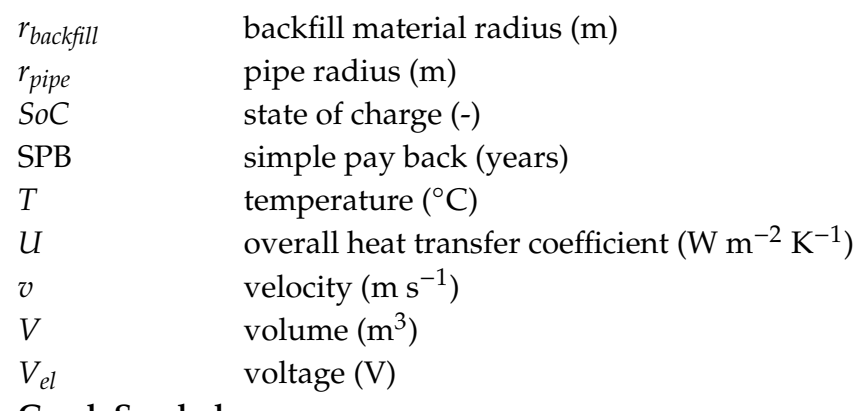

\section{Greek Symbols}

$\Delta$

$\varepsilon$

$\eta$

$\theta$

$\rho$

$\rho_{S}$

Subscripts

$a$

act

$\operatorname{avg}$

$c$

conv

cool

$d$

DHW

E

el

el,devices

ex

FromLIB

from $G R I D$

heat

i

I

in

inf

min

NG

ORC

out

$p$

PS

PV

renw

RS

$s$

sup

$t$

th

toBUILD

toEV

toGRID

toLIB

$u$ difference (-)

long wave emissivity (-)

efficiency (-)

time step (s)

density $\left(\mathrm{kg} \mathrm{m}^{-3}\right)$

solar reflectance (-)

ambient

activation

average

referred to battery charge

convective

cooling

referred to battery discharge

domestic hot water

energy

electric

electric devices of the building

exchange

electric energy withdrawn from lithium-ion battery

electric energy withdrawn from national electric grid

heating

number of nodes of ground-coupled heat exchanger

inverter

inlet

inferior

minimum

natural gas

organic Rankine cycle

output

primary energy

proposed system

photovoltaic field

the renewable energy produced

reference system

soil

superior

the value of a parameter in time step

thermal

electric energy supplied to building

to evaporator of ORC machine

electric energy sent to national electric grid

electric energy sent to the lithium-ion battery

user 


\section{References}

1. Calise, F.; di Vastogirardi, G.D.N.; d'Accadia, M.D.; Vicidomini, M. Simulation of polygeneration systems. Energy 2018, 163, 290-337. [CrossRef]

2. Calise, F.; d'Accadia, M.D.; Libertini, L.; Quiriti, E.; Vanoli, R.; Vicidomini, M. Optimal operating strategies of combined cooling, heating and power systems: A case study for an engine manufacturing facility. Energy Convers. Manag. 2017, 149, 1066-1084. [CrossRef]

3. Calise, F.; d'Accadia, M.D.; Vicidomini, M.; Ferruzzi, G.; Vanoli, L. Design and Dynamic Simulation of a Combined System Integration Concentrating Photovoltaic/Thermal Solar Collectors and Organic Rankine Cycle. Am. J. Eng. Appl. Sci. 2015, 8, 100-118. [CrossRef]

4. Uris, M.; Linares, J.I.; Arenas, E. Feasibility assessment of an Organic Rankine Cycle (ORC) cogeneration plant (CHP/CCHP) fueled by biomass for a district network in mainland Spain. Energy 2017, 133, 969-985. [CrossRef]

5. Buonomano, A.; Calise, F.; Palombo, A.; Vicidomini, M. Energy and economic analysis of geothermal-solar trigeneration systems: A case study for a hotel building in Ischia. Appl. Energy 2015, 138, 224-241. [CrossRef]

6. Calise, F.; Cipollina, A.; d'Accadia, M.D.; Piacentino, A. A novel renewable polygeneration system for a small Mediterranean volcanic island for the combined production of energy and water: Dynamic simulation and economic assessment. Appl. Energy 2014, 135, 675-693. [CrossRef]

7. Calise, F.; d'Accadia, M.D.; Vicidomini, M.; Scarpellino, M. Design and simulation of a prototype of a small-scale solar CHP system based on evacuated flat-plate solar collectors and Organic Rankine Cycle. Energy Convers. Manag. 2015, 90, 347-363. [CrossRef]

8. Patel, B.; Desai, N.B.; Kachhwaha, S.S.; Jain, V.; Hadia, N. Thermo-economic analysis of a novel organic Rankine cycle integrated cascaded vapor compression-absorption system. J. Clean. Prod. 2017, 154, $26-40$. [CrossRef]

9. Tchanche, B.F.; Pétrissans, M.; Papadakis, G. Heat resources and organic Rankine cycle machines. Renew. Sustain. Energy Rev. 2014, 39, 1185-1199. [CrossRef]

10. Olabi, A.G. Renewable energy and energy storage systems. Energy 2017, 136, 1-6. [CrossRef]

11. Yang, Y.; Bremner, S.; Menictas, C.; Kay, M. Battery energy storage system size determination in renewable energy systems: A review. Renew. Sustain. Energy Rev. 2018, 91, 109-125. [CrossRef]

12. Zhou, C. Hybridisation of solar and geothermal energy in both subcritical and supercritical Organic Rankine Cycles. Energy Convers. Manag. 2014, 81, 72-82. [CrossRef]

13. Tourkov, K.; Schaefer, L. Performance evaluation of a PVT/ORC (photovoltaic thermal/organic Rankine cycle) system with optimization of the ORC and evaluation of several PV (photovoltaic) materials. Energy 2015, 82, 839-849. [CrossRef]

14. Kosmadakis, G.; Landelle, A.; Lazova, M.; Manolakos, D.; Kaya, A.; Huisseune, H.; Karavas, C.-S.; Tauveron, N.; Revellin, R.; Haberschill, P.; et al. Experimental testing of a low-temperature organic Rankine cycle (ORC) engine coupled with concentrating PV/thermal collectors: Laboratory and field tests. Energy 2016, 117, 222-236. [CrossRef]

15. Bicer, Y.; Dincer, I. Analysis and performance evaluation of a renewable energy based multigeneration system. Energy 2016, 94, 623-632. [CrossRef]

16. Galindo Noguera, A.L.; Castellanos, L.S.M.; Lora, E.E.S.; Cobas, V.R.M. Optimum design of a hybrid diesel-ORC / photovoltaic system using PSO: Case study for the city of Cujubim, Brazil. Energy 2018, 142, 33-45. [CrossRef]

17. Dow Chemical Company. Dowtherm A-Heat Transfer Fluid_Product Technical Data; Dow Chemical Company: Midland, MI, USA, 1997; Available online: https://www.dow.com/content/dam/dcc/documents/en-us/apptech-guide/176/176-01407-01-dowtherm-q-heat-transfer-fluid-technical-manual.pdf?iframe=true (accessed on 5 May 2019).

18. Drake, S.J.; Martin, M.; Wetz, D.A.; Ostanek, J.K.; Miller, S.P.; Heinzel, J.M.; Jain, A. Heat generation rate measurement in a Li-ion cell at large C-rates through temperature and heat flux measurements. J. Power Sources 2015, 285, 266-273. [CrossRef]

19. Khandelwal, A.; Hariharan, K.S.; Gambhire, P.; Kolake, S.M.; Yeo, T.; Doo, S. Thermally coupled moving boundary model for charge-discharge of LiFePO4/C cells. J. Power Sources 2015, 279, 180-196. [CrossRef] 
20. Grandjean, T.; Barai, A.; Hosseinzadeh, E.; Guo, Y.; McGordon, A.; Marco, J. Large format lithium ion pouch cell full thermal characterisation for improved electric vehicle thermal management. J. Power Sources 2017, 359, 215-225. [CrossRef]

21. Ahmadian, A.; Sedghi, M.; Elkamel, A.; Fowler, M.; Golkar, M.A. Plug-in electric vehicle batteries degradation modeling for smart grid studies: Review, assessment and conceptual framework. Renew. Sustain. Energy Rev. 2018, 81, 2609-2624. [CrossRef]

22. Dong, T.; Peng, P.; Jiang, F. Numerical modeling and analysis of the thermal behavior of NCM lithium-ion batteries subjected to very high C-rate discharge/charge operations. Int. J. Heat Mass Transf. 2018, 117, 261-272. [CrossRef]

23. Calise, F.; Cappiello, F.L.; Cartenì, A.; d'Accadia, M.D.; Vicidomini, M. A novel paradigm for a sustainable mobility based on electric vehicles, photovoltaic panels and electric energy storage systems: Case studies for Naples and Salerno (Italy). Renew. Sustain. Energy Rev. 2019, 111, 97-114. [CrossRef]

24. Klein, S.A. Solar Energy Laboratory, TRNSYS. A Transient System Simulation Program; University of Wisconsin: Madison, WI, USA, 2006.

25. Palmieri, V. European Patent Application. European Patent 2672 194, 23 March 2012.

26. Perers, B.; Bales, C. Report of IEA SHC-Task 26, Solar Combisystems. 2002. Available online: https://www.iea.org/ (accessed on 8 May 2019).

27. Institut für Thermodynamik und Wärmetechnik (ITW). Test report n. 11COL1028. 2012. Available online: https://www.igte.uni-stuttgart.de/ (accessed on 8 May 2019).

28. Calise, F.; Dentice d'Accadia, M.; Piacentino, A. A novel solar trigeneration system integrating PVT (photovoltaic/thermal collectors) and SW (seawater) desalination: Dynamic simulation and economic assessment. Energy 2014, 67, 129-148. [CrossRef]

29. Calise, F.; d'Accadia, M.D.; Vanoli, R.; Vicidomini, M. Transient analysis of solar polygeneration systems including seawater desalination: A comparison between linear Fresnel and evacuated solar collectors. Energy 2019, 172, 647-660. [CrossRef]

30. Buonomano, A.; Calise, F.; d'Accadia, M.D.; Vicidomini, M. A hybrid renewable system based on wind and solar energy coupled with an electrical storage: Dynamic simulation and economic assessment. Energy 2018, 155, 174-189. [CrossRef]

31. Tervo, E.; Agbim, K.; DeAngelis, F.; Hernandez, J.; Kim, H.K.; Odukomaiya, A. An economic analysis of residential photovoltaic systems with lithium ion battery storage in the United States. Renew. Sustain. Energy Rev. 2018, 94, 1057-1066. [CrossRef]

32. Santos, M.; André, J.; Costa, E.; Mendes, R.; Ribeiro, J. Design strategy for component and working fluid selection in a domestic micro-CHP ORC boiler. Appl. Therm. Eng. 2020, 169, 114945. [CrossRef]

33. Iranmanesh, A.; Mehrabian, M.A. Dynamic simulation of a single-effect LiBr-H2O absorption refrigeration cycle considering the effects of thermal masses. Energy Build. 2013, 60, 47-59. [CrossRef] 